\title{
Nanotoxicology and Nanosafety: Safety-by-Design and Testing at a Glance
}

\author{
Aleksandra Zielińska ${ }^{1,2}{ }^{\circledR}$, Beatriz Costa ${ }^{1}$, Maria V. Ferreira ${ }^{1}$, Diogo Miguéis ${ }^{1}$, \\ Jéssica M. S. Louros ${ }^{1}$, Alessandra Durazzo ${ }^{3}{ }^{\mathbb{D}}$, Massimo Lucarini ${ }^{3}$, Piotr Eder ${ }^{4}{ }^{(\mathbb{D}}$,

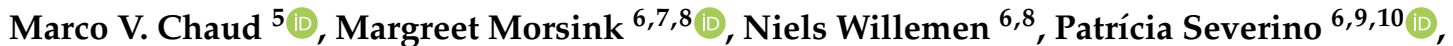 \\ Antonello Santini $11, * \mathbb{D}$ and Eliana B. Souto $1,12, * \mathbb{B}$
}

1 Department of Pharmaceutical Technology, Faculty of Pharmacy, University of Coimbra, Pólo das Ciências da Saúde, Azinhaga de Santa Comba, 3000-548 Coimbra, Portugal; zielinska-aleksandra@wp.pl (A.Z.); beafecosta@gmail.com (B.C.); mariavferreira00@gmail.com (M.V.F.); diogodmigueis@gmail.com (D.M.); jessicamslouros@gmail.com (J.M.S.L.)

2 Institute of Human Genetics, Polish Academy of Sciences, Strzeszyńska 32, 60-479 Poznań, Poland

3 CREA-Research Centre for Food and Nutrition, Via Ardeatina 546, 00178 Rome, Italy; alessandra.durazzo@crea.gov.it (A.D.); massimo.lucarini@crea.gov.it (M.L.)

4 Department of Gastroenterology, Dietetics and Internal Diseases, Poznan University of Medical Sciences, Przybyszewskiego 49, 60-355 Poznań, Poland; piotr.eder@op.pl

5 Laboratory of Biomaterials and Nanotechnology, University of Sorocaba-UNISO, Sorocaba 18023-000, Brazil; marco.chaud@prof.uniso.br

6 Center for Biomedical Engineering, Department of Medicine, Brigham and Women\& Hospital, Harvard Medical School, 65 Landsdowne Street, Cambridge, MA 02139, USA; m.a.j.morsink@student.utwente.nl (M.M.); n.g.a.willemen@student.utwente.nl (N.W.); pattypharma@gmail.com (P.S.)

7 Translational Liver Research, Department of Medical Cell BioPhysics, Technical Medical Centre, Faculty of Science and Technology, University of Twente, 7522 NB Enschede, The Netherlands

8 Department of Developmental BioEngineering, Faculty of Science and Technology, Technical Medical Centre, University of Twente, 7522 NB Enschede, The Netherlands

9 Nanomedicine and Nanotechnology Laboratory (LNMed), Institute of Technology and Research (ITP), University of Tiradentes (Unit), Av. Murilo Dantas, 300, Aracaju 49010-390, Brazil

10 Tiradentes Institute, 150 Mt Vernon St, Dorchester, MA 02125, USA

11 Department of Pharmacy, University of Napoli Federico II, 80131 Napoli, Italy

12 CEB-Centre of Biological Engineering, University of Minho, Campus de Gualtar, 4710-057 Braga, Portugal

* Correspondence: asantini@unina.it (A.S.); ebsouto@ff.uc.pt (E.B.S.); Tel.: +39-81-253-9317 (A.S.); +351-239-488-400 (E.B.S.)

Received: 9 May 2020; Accepted: 23 June 2020; Published: 28 June 2020

check for updates

\begin{abstract}
This review offers a systematic discussion about nanotoxicology and nanosafety associated with nanomaterials during manufacture and further biomedical applications. A detailed introduction on nanomaterials and their most frequently uses, followed by the critical risk aspects related to regulatory uses and commercialization, is provided. Moreover, the impact of nanotoxicology in research over the last decades is discussed, together with the currently available toxicological methods in cell cultures (in vitro) and in living organisms (in vivo). A special focus is given to inorganic nanoparticles such as titanium dioxide nanoparticles $\left(\mathrm{TiO}_{2} \mathrm{NPs}\right)$ and silver nanoparticles (AgNPs). In vitro and in vivo case studies for the selected nanoparticles are discussed. The final part of this work describes the significance of nano-security for both risk assessment and environmental nanosafety. "Safety-by-Design" is defined as a starting point consisting on the implementation of the principles of drug discovery and development. The concept "Safety-by-Design" appears to be a way to "ensure safety", but the
\end{abstract}


superficiality and the lack of articulation with which it is treated still raises many doubts. Although the approach of "Safety-by-Design" to the principles of drug development has helped in the assessment of the toxicity of nanomaterials, a combination of scientific efforts is constantly urgent to ensure the consistency of methods and processes. This will ensure that the quality of nanomaterials is controlled and their safe development is promoted. Safety issues are considered strategies for discovering novel toxicological-related mechanisms still needed to be promoted.

Keywords: nanotoxicology; nanosafety; nanomaterials; risk assessment; toxicity tests; nanoparticles; human health; Safety-by-Design; biological systems

\section{Introduction}

Nanomaterials (NMs) are natural or manufactured materials based on nanosized particles in a disaggregated state or in the form of an aggregate/agglomerate [1]. The number-size distribution of 50\% or more of the particles which have one or more external dimensions in the size range comprised between 1 and 100 nanometers [2,3]. Due to the small size of the particles and changes in their inner structure, NMs can have different properties that stem from a higher surface area to volume ratio [4]. Therefore, the physicochemical properties of NMs may differ from the properties of granular substances or larger particles [5].

There is a huge demand for a definition of NMs [6,7]. On the other hand, the life cycle assessment of NMs has been recognized as a significant tool for regularly evaluating the potential environmental impacts of manufactured nanomaterial during their complete life cycles [8], and it is schematically presented in Figure 1.

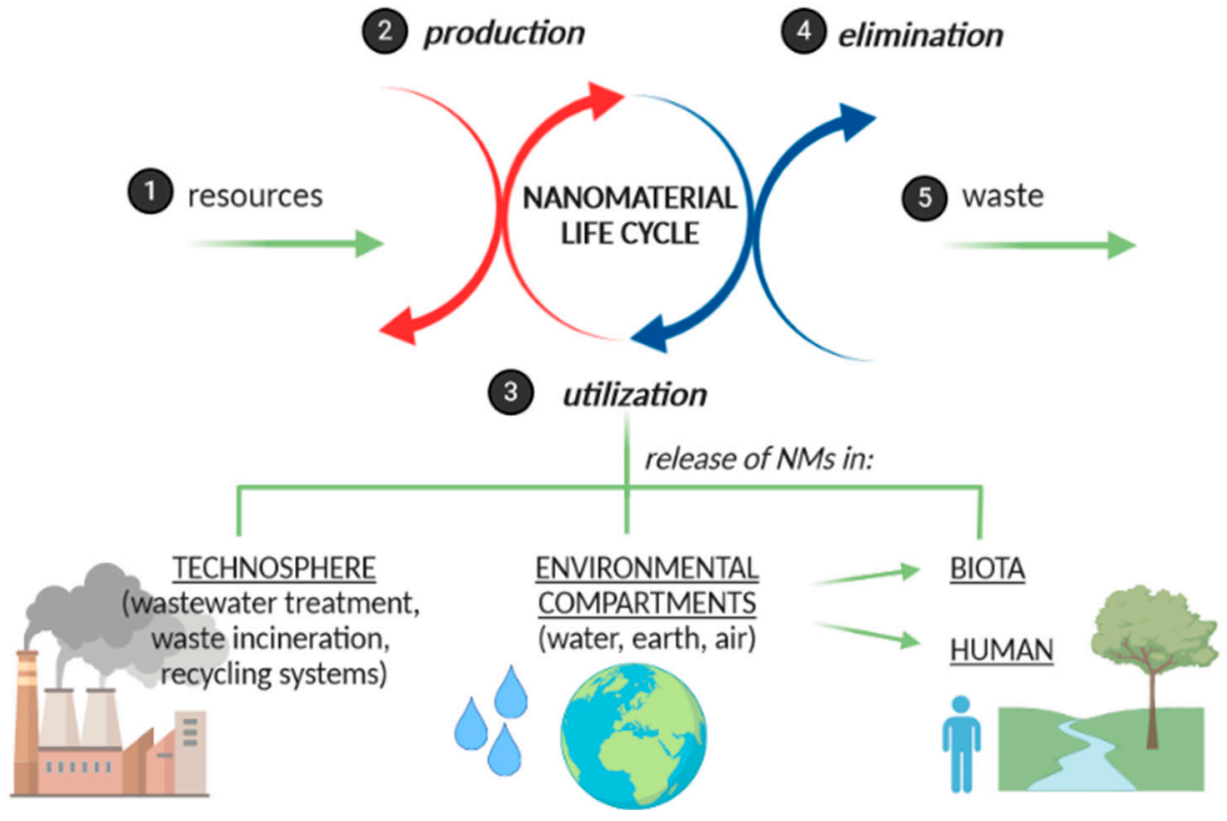

Figure 1. The impact of nanomaterial life cycle on the environment.

For a long time, it has been assumed that NMs have a similar toxicity to materials of larger size [9]. However, studies have shown that nanosized materials exhibit different physicochemical properties from 
those of the source material (thereby changing their reactivity in biological systems). It calls into the question whether applying conventional methodologies to evaluate the adverse effects of NMs is still valid [10]. According to "REACH" (Registration, Evaluation, Authorization and restriction of Chemical Substances), the safety assessment of NMs should follow the risk assessment methodology adopted for conventional chemicals, which is based on the following requirements [11]: (1) effects evaluation, (2) exposure assessment, and (3) risk characterization (Figure 2). Step 1 includes the evaluation of effects. The risk quotient is considered acceptable (higher than 1) when the estimated exposure value is lower than the concentration of the agent, in which no adverse effect was observed in the experimental study carried out to evaluate the point under study-for example, inhalation toxicity or genotoxicity. If it is necessary to carry out in vitro and/or in vivo experiments in order to assess the effects, other procedures to characterize the NMs under study may also be recommended. This includes collecting information on the most relevant physicochemical parameters that may influence the toxicity, i.e., size distribution, aggregation/agglomeration status, shape, surface area, reactivity, water solubility, surface properties, and long-term stability [11,12]. Step 2 includes the identification of all potential sources of exposure [13]. Thus, it is important to understand the full manufacturing process and the most likely routes of exposure. This is also relevant for choosing the appropriate testing strategy and for making recommendations on risk prevention measures (Step 3) [14].

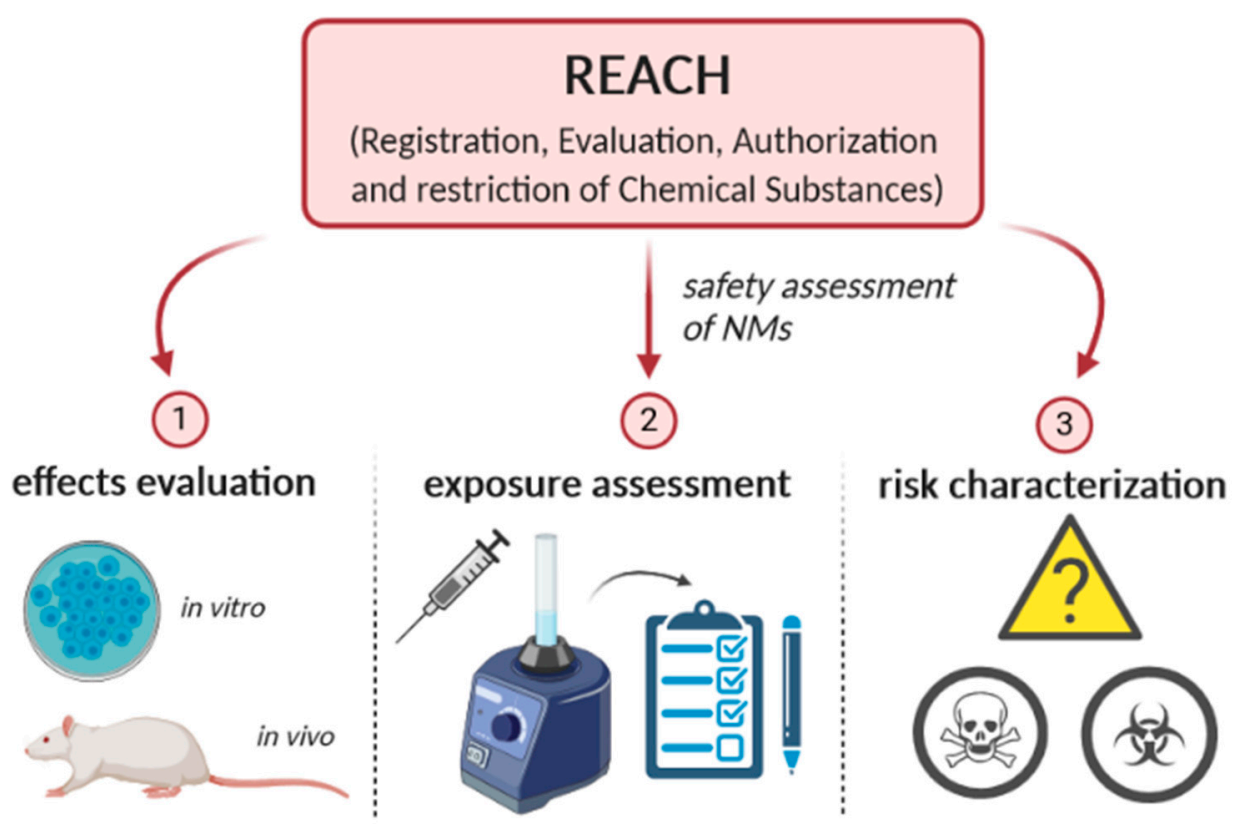

Figure 2. The risk assessment methodology for nanomaterials (NMs) based on Registration, Evaluation, Authorization and restriction of Chemical Substances (REACH) requirements.

The NanoRoadMap Project, funded by the European Commission, has develop guidelines for the nanotechnological development in three major areas, namely Energy, Materials and Health, and Medical Systems. The project created new possible applications of NMs, as described in this fragment: "with the development of current and emerging technology to manipulate matter on a nanoscale and atomic scale, we have reached a point where any viable molecular structure to include a large number of nuclides can be designed and built at will" [6]. Therefore, NMs are nowadays applied in multiple fields, such as agriculture [15] or engineering, to develop new processes and new tools to manipulate matter at the atomic level [16]. For example, NMs can be used for the safe storage of hydrogen for use as a clean fuel [17]. In nanomedicine, NMs are 
applied in the mapping and diagnosis of diseases with the so-called "lab-on-a-chip" [18], the arrays of nanosensors [19], magnetic nanoparticles [20], and "quantum dots" [21,22]. Moreover, NMs can be applied as molecular nanostructures to reinforce asphalt and concrete [23,24]. Environmentally, NMs are also applied for purification and desalination [25], as well as in water treatment and control, in treating the effects of air pollution and in reducing the time of degradation of plastic [26]. In addition, NMs can be applied in food processing and respective storage, and as nutraceutical matrices [27-31].

\section{Formulating Nanomaterials in Innovative Products}

The increased use of NMs in the global industry has led to concerns about potential toxicological effects on the human health and the environment. Nowadays, the control and regulation of NMs is mandatory. Thus, the European Research Council and EURO-NanoTox have constituted a so called "nano-security group", which has been appointed to assess the safety of a newly designed nanomaterial [11].

The European regulation for pharmaceutic and cosmetic products demands the confirmation of the nanosafety by special nanotoxicological tests [1]. The same holds for the agricultural and food sectors. It should be noted that the use of NMs as an ingredient in disinfectants, preservatives, pest control products, and others is subject to authorization based on a separate assessment of the nanospecific risks. Additionally, if there is no specific regulation about the use of NMs in chemical products, the product is subject to EC Regulation No. 1907/2006 (REACH) [11].

The authorities aim to emphasize reproducible studies in the context of a correct assessment of nano-security, meaning the need to establish a reproducible process to produce and test the biosafety levels of NMs [32]. The studies need to be well structured and optimized, with a precisely defined protocol for the possible understanding of the level of exposure and its distribution in the ecosystem and in the human body, thereby allowing the correct evaluation of the safety of the product [3,32]. Therefore, it will be essential to control and verify a series of characteristics and challenges before placing products on the market [1], including among others (1) the plasmonic properties, (2) gap band factor, (3) surface coating, (4) particle size, (5) surface electrical charge, (6) morphology, and (7) phase stability.

The plasmonic properties of optically active nanoparticles or noble metals (e.g., gold, copper, and silver) possess strong interactions with the incident light and can amplify the local electromagnetic field, thus influencing some of the biological characteristics of the particles [33]. These optical NMs can convert light into thermal heat and, consequently, they can be used in photothermal therapy. It is worth underlining that during the periodic characterization of the interaction of the biological system, it is possible to generate false results, either positive or negative, influencing nanotoxicity [34]. This phenomenon should be the focus of further investigation.

The excitation of NMs with an appropriate band interval (gap band factor) can impact their optical and redox properties, as well as the risk of generating reactive oxygen species [35]. Moreover, the enthalpy becomes less negative, and the toxicity of the material increases as the energy of the conducting band of the metal oxide nanoparticles hydrates [36].

The surface coating affects the surface load, where it can either keep the particle stable or be designed such that it can recognize and react with specific bonds [37]. It can alter the reactivity of the particle and it governs many alternative functions, thereby stressing its importance for nanotoxicity.

The particle size governs the surface area and mass of the particle unit. Thus, the size of the nanoparticles is an important parameter and the most often studied. Density and surface area vary per unit of mass, which increases with size [37,38].

The surface electrical charge of the nanoparticles (positively or negatively charged) influences the interaction of the NMs with subsystems or biological membranes in an aqueous environment [32]. Logically, if the particle is negatively charged, it will be attracted to positively charged surfaces (and vice versa). 
Generally, the positively charged nanoparticles are recognized as more toxic and may even damage the membrane of cells. Moreover, they can interact with enzymes, proteins, and DNA [39] with an increased risk of genotoxicity $[40,41]$.

The wide variety of shapes and morphologies of the NMs can affect their stability, transport, surface adsorption, and absorption by biological systems [42].

The large-scale phase diagrams do not predict the phases of the nanoparticles, as there is a difference in phase stability between the large-scale dynamics and the nanoscale [43]. This process is more frequent during the nanoparticle synthesis at the temperature below the melting point of the ingredients. The high curvature and the high surface area of NMs are the generators of this effect [44]. The synthesis methods used for the production of NMs may lead to a series of invalid features in the crystals and their densities [44]. The presence of impurities in NMs may increase their instability, leading to i.e., Ostwald ripening - a phenomenon that describes the change of an inhomogeneous structure over time [45]. This can be justified by the indirect proportionality that exists between the internal pressure and the diameter of the particles.

The control of the mean particle size, surface charge and chemical modification, morphology, porosity, and phase stability is instrumental for quality assessment and safety. The first techniques used for the physicochemical characterization of NMs are the Dynamic Light Scattering to measure the mean particle size and polydispersity index, and the zeta potential to provide information about the electrokinetic potential in colloidal dispersions estimating the stability of NMs over time and in different types of fluids. Microscopic techniques that characterize morphology include the Scanning Electron Microscopy and Transmission Electron Microscopy, depending on the size and material used in the production of NMs. Other techniques, as X-ray diffraction and thermal analysis (e.g., differential scanning calorimetry) are employed to observe specific characteristics as polymorphisms and chemical interactions. After physicochemical characterization, in vitro in selected cell lines and pre-clinical studies are usually followed (Figure 3).

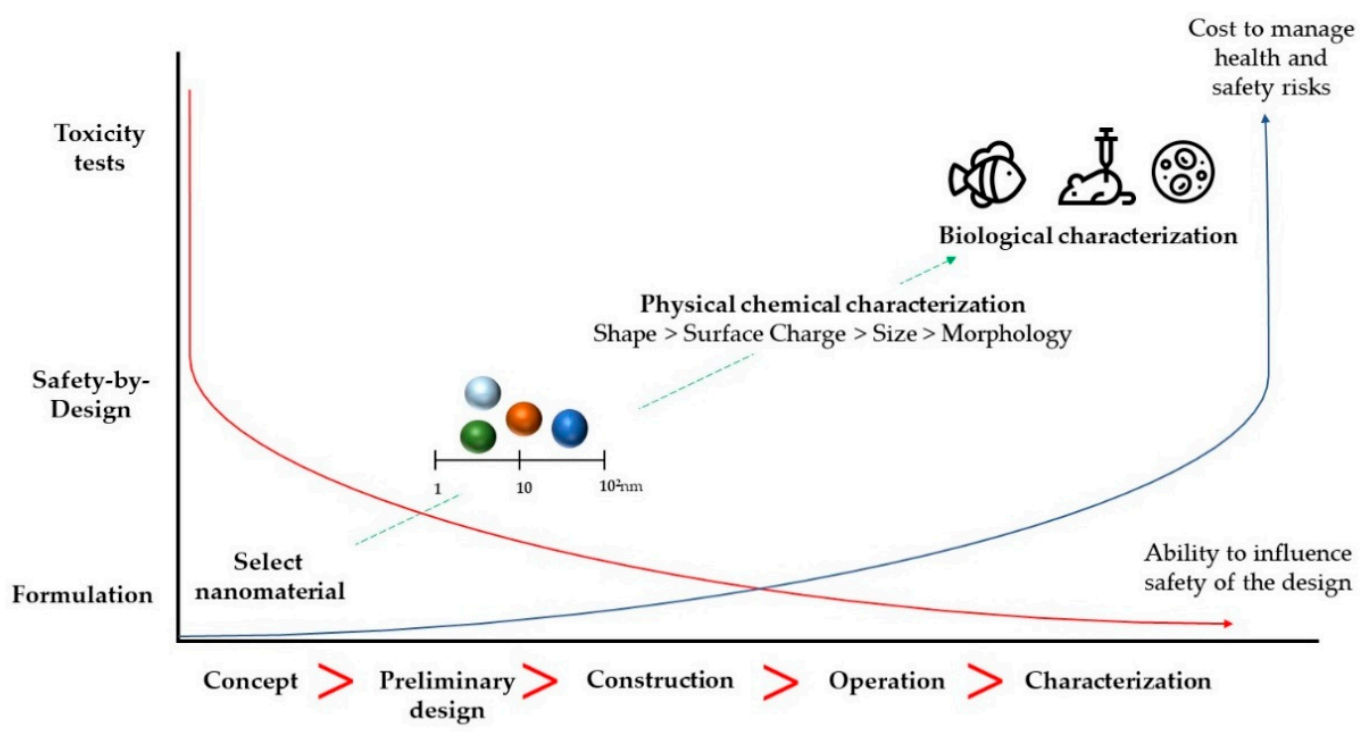

Figure 3. Relevant properties of nanomaterials in view of their safety assessment and the influence over a product's lifecycle. 


\section{3. "Safety-by-Design" of Nanomaterials}

Nanomaterials (NMs) have different properties that may influence their toxicological profile [3]. Thus, official nanotoxicity guidelines are established to allow the safe design and application of NMs [32,41,46]. These include (1) the particle size, as the toxicity for and uptake by cells will increase with smaller sizes of the NMs; (2) the particle charge, as NMs with positive charge have a higher toxicity due to increased interactions with negatively charged biological surfaces [47]; (3) the ionic dissolution, as a higher ionic dissolution leads to a higher toxicity, and (4) the shape, as anisotropic or rod-shaped NMs are less efficient and can cause significant damage in the near infrared, which can destroy the target cells [32,48].

The main concern for nanotoxicologists is the protection of the human health while identifying the risk factors caused by NMs. This identification is a huge challenge, since people can easily be exposed to NMs that are integrated in compounds manufactured by uncontrolled, non-purified, and complex processes [49]. Therefore, care must be taken when assessing the potential risk of the projected nanomaterials [50], and the following outlines should be taken into consideration: (1) to select the NMs for nanotoxicology research and to create environments with exposure conditions (physical, chemical, and biotic) and exposure times; (2) to describe all of the characteristics of the means of exposure, as well as present metadata that allow cross-comparisons in detail; (3) to select forms of designed NMs (characterized by the process of a risk assessment in order to ensure a homogeneous assessment) with concentrations in scale; (4) to examine and choose several end points for the characterization of designed NMs (e.g., physicochemical properties and characterization of toxicity); (5) to quantify the load and compartmentalization of designed NMs, thereby enabling a comparison of the effective doses in biological response; (6) to follow experimental control treatments; and (7) to approach in the appropriate form of rapid screening in order to obtain relevant knowledge. It should be noted that most of the studies are carried out under specific conditions of exposure and they do not present highly significant results. Apart from the characterization and identification, several other risk factors of NMs include: (1) finding common processes that release large amounts of designed NMs (either due to the lack of large-scale nano-industry or due to the integration of NMs with other compounds); (2) the aggregation of NPs with other (non-toxic) compounds during the release process; (3) the risk identification of NMs during in vitro testing; (4) understanding the complexity of the interaction of NMs with biological systems; (5) the fact that the smallest difference between NMs can lead to major changes in the NMs interactions with biological systems in vivo; (6) the complexity of biological systems, associated with the great variability of NMs, as well as their dynamic transformation; (7) the lack of instruments, concordant protocols, and theoretical understanding that hinder the reproducibility of experiments; and (8) the lack of standardized experiments with biomarkers, demonstrative functional analyses, dosing, and statistics [51].

"Safety-by-Design" ( $\mathrm{SbD}$ ) is taken as a starting point when engineering a novel NM, thereby strictly following the principles of Drug Discovery and Development (DDD) throughout the whole process of product development [52]. The belief behind "Safety-by-Design" (SbD) is to engineer unwanted effects out of the NMs by implementing the knowledge of the NMs' adverse effects on the environment and human health into the process of designing the desired NMs (Figure 4). In the construction industry, the main focus is on modifying the initial design in order to prevent accidents in the workplace and minimize the negative effects on the health. The development of processes that reduce the risk of the product toxicity have been observed as well in the field of green chemistry [53].

The NANoREG and NANoREG II, started in 2015, consist of two European projects that articulate the meaning and practice of SbD [53,54]. Firstly, functionality and safety are assessed in an integrated manner in the course of product development. Secondly, these rules are based on three pillars: safe design, safe production, and safe use. The support of the "safe innovation" approach, whereby the concept of SbD 
is combined with "normative readiness", is a necessary information and knowledge within the innovation chain, ensuring compliance with the standards [52].

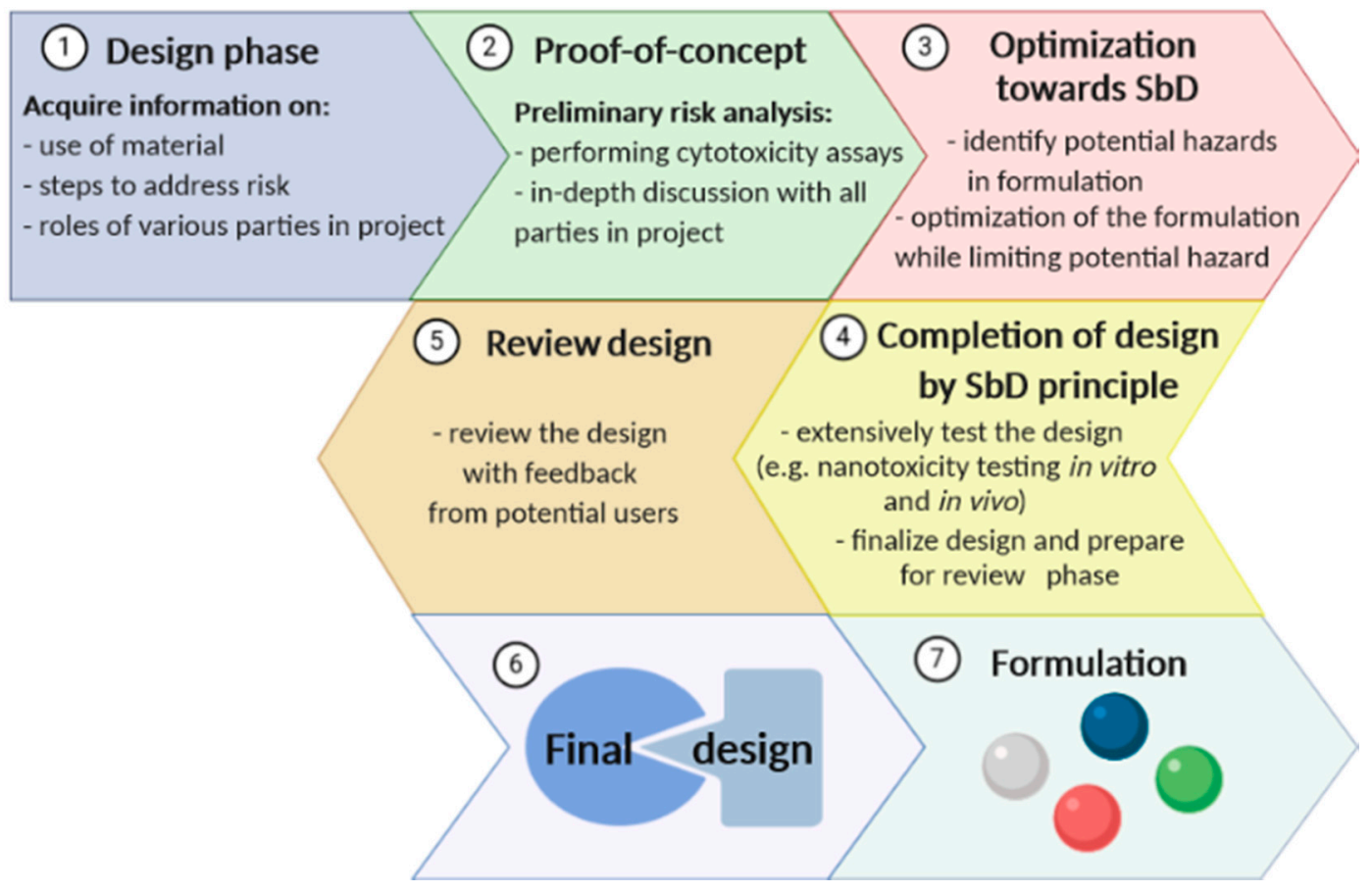

Figure 4. Schematic of the Safety-by-Design principle.

Security is the central concept of $\mathrm{SbD}$, but it is important to note that absolute security is never reached. This may lead to the question of what is sufficiently safe, who should define the levels of the security, and how this decision is made. It follows that it may be more appropriate to use the expression "safer" instead of the absolute terms "safe" and "security", for instance [53]. However, most of the projects continue to use the absolute terms of security and protection, thereby failing to recognize the relational value of this concept or the underlying challenges [53]. SbD tries to rephrase the question of safety to: "Is it inherently safe?" and "Can we design the product while ensuring its safety?" In this way, the political challenges regarding with standardized risk assessment are accepted. These aspects require a great interaction of technical, social, cultural, political, educational, and economic considerations. According to $\mathrm{SbD}$, the collaboration between scientists and innovators can generate new challenges and concerns, although on the other hand, the result from these collaborations may allow the acceptance and realization of $\mathrm{SbD}$, as well as affecting public confidence, both at the level of research and the level of products [53].

At all stages of the DDD process, the pharmaceutical industry uses several methods to assess the risks of toxicity. According to the REACH regulation, the focus on the toxicity tests occurs essentially as soon as the product has entered the market. However, it has been verified that the vision of $\mathrm{SbD}$ for the projected NMs has been approximated to the principles of DDD, instead of the current models of normative toxicology [55].

In DDD, in vitro and in silico screenings are carried out in order to avoid the toxicity and failures associated with safety in development. "Fail early, fail frequently" is the DDD discovery paradigm [56]. It motivates the attempt to reduce future losses without canceling the need to carry out toxicological assessments in vivo. In turn, early in vitro screening in DDD is performed with the objective of determining targets and non-targets in which a compound interacts in order to avoid side effects [57]. For this reason, 
it can also be called a pharmacological profile. However, despite the attempts to solve the toxicity problem, the safety concept designed for the drug is not complete. It is incorrect to state that all of the adverse events of a drug are known when it reaches the market. Until the drug is commercialized, it is carefully investigated, but there is no guarantee that they will not be removed later for safety reasons. For example, in the WITHDRAWN database, there are data that contain more than 500 drugs withdrawn from the market [58].

The implementation of SbD has pushed nano-security research away [53]. However, when SbD is presented as a way for nano-security to keep pace with innovation, it is assumed that it will require new toxicological tests and will reduce the time and workload required for "regulatory readiness". This will depend on the predictability of the simplified tests. SbD tries to guarantee safety, despite the problems that are constantly arising. However, safety tests precede the identification of risks, which themselves precede the understanding of the mechanism; this in turn precedes the prognosis of SbD. Thereupon, "Safety-by-Design" cannot be used to overcome the problems that may arise after toxicological risk assessments for proposed nanomaterials.

\section{Nanotoxicology: From Past Lights and Shadows to Current Concerns}

The term nanotoxicology has only gained interest from the last two decades onwards $[32,41,46]$. Since that time, many advances have been made in this area. Two important factors led to a rapid progress in this branch of science [59]. Firstly, "the large-scale production of diversified nanomaterials and remarkable progress in the development of new types of nanomaterials with disconcerting physical and chemical characteristics" [60]. Second, many studies based on constantly improving NMs have stimulated research in Physics, Chemistry, and Bioengineering, leading to new interdisciplinary progress in Nanoscience and its applications. For example, there has been huge progress in the bioapplication of NMs [60].

Nanomedicine and nanotoxicology are strictly linked, since both can explore the same mechanisms and affect identical metabolic pathways [61]. Bearing in mind that newly NMs can exhibit specific toxicity, it is necessary to summarize and reassess the data accumulated from time to time, thereby ensuring safety [62]. The development of current nanotoxicology studies is surprising, mainly in the biological area $[41,47,63]$. For example, the biosynthesis of insecticidal nanoparticles mediated by plants and other botanical products is constantly developed [64-66].

Nanotoxicology has become a subdiscipline at the interface of toxicology and NMs [60]. Due to their extremely small size and large surface area to volume ratio, NMs have different properties compared to their larger equivalents that may enable unpredictable interactions with cells and tissues. Nanotoxicology tends to highlight the possible toxic interactions between NMs and different biological systems (cells, tissues, and living organisms) [32]. Several years of research have showed that the interactions of NMs with the environment and with cells of living organisms are highly complex $[41,46,67,68]$. However, it has not been revealed how the properties (both physicochemical and morphological) of NMs can influence these interactions [69-71].

The morphological and physicochemical properties of NMs have a great impact on the interaction with biological cells and may influence their toxicity. Nanotoxicology is responsible for the analysis of the toxic effects of NMs, especially since the materials' size plays a significant role in the toxicity of NMs [10,72]. The concept of nanotoxicology is based on different parameters, such as the size, surface area, morphology, composition, surface chemistry, agglomeration/aggregation phenomena, etc. In fact, all of these parameters have a critical impact on the determination of the nanoparticles' dose and consequently, the precise assessment of their toxicity. However, determining the maximum exposure values of toxic NMs would be impossible without in vitro and in vivo tests. Many strategies to study the nanotoxicology and the interaction of NMs with biological systems are already in place [41,46]. Initial studies on the 
toxicity of NMs were carried out in the last decade of the 20th century, already revealing that materials of a micrometric scale did not present toxicity, while materials at a nanometric scale might have some toxic effect $[41,46,61]$.

\section{Toxicity Tests}

Toxicity tests can be performed on cell cultures (in vitro) and in living organisms (in vivo) such as fish, mice, or rats $[73,74]$. There are several standardized toxicological tests that are available to assess the biological response of a chemical substance. However, there is no standardization for the assessment of nanoparticles toxicity. It causes many difficulties in the comparison of the results regarding the toxicity of the tested ingredients. Most of the toxicity tests for NMs have been performed in vitro, using cultures of mammalian cells that were extracted from the most different parts of the body (e.g.,: brain, lungs, heart, skin and liver) [75]. Although in vitro tests are less expensive than in vivo and the results may be obtained in a shorter time, it is not possible to infer potential implications related with the human health based on the in vitro only [76].

Since continental and marine waters would be the main receiving compartment, in vivo tests were mainly carried out in aquatic organisms that would reflect the impact of nanomaterials on the environment [73]. During the contact with animals, the variation of the NMs concentration allows to calculate statistically the indicators that will allow the comparison of toxicity between different nanomaterials and/or between nanomaterials and traditional chemical substances. The most used evaluation parameters are $[12,77]$ the $\mathrm{LC}_{50}$ (i.e., concentration of nanomaterial that causes the death of $50 \%$ of the population, LOEC (i.e., low concentration that causes a noticeable effect on the organism), and NOEC (i.e., maximum concentration, at which no effect is observed on the organisms). Moreover, experimental animal trials have advantages, with one of the important ones being the assessment of the kinetics of nanoparticles through absorption, distribution, metabolism, and excretion (ADME).

\subsection{In Vitro}

\subsubsection{D Models}

The most commonly used method to determine NM toxicity on a 2D platform is the exposure of an NM dispersion to adherent cells, where the NMs are dispersed in the media. This method in itself is straightforward; however, obtaining a reproducible and homogeneous NM dispersion in the media poses a challenge. For example, many dispersions are diluted by sonication. Yet, the duration and strength of sonication are two parameters that influence the NM size distribution and agglomeration state and thus also influence the cellular uptake and NM toxicity greatly [78].

Another frequently used method is the NM surface presentation. In this method, cells are seeded on top of a NM layer, which is immobilized on a substrate. Thus, the NMs cannot agglomerate and remain static on the surface. Moreover, it offers additional control over the NM density on the surface and the NM dose per cell, thereby optimizing the cell to cell dose variability.

One of the major drawbacks in the previous systems is the inability of using buoyant NMs. Inverted cell culture systems are preferable for these, since the cells are attached to a coverslip and suspended in the media from above $[79,80]$. Some NMs have shown nanotoxicity in this method and not in upright exposure where cells are attached to the bottom [80,81]. However, this method cannot be used for all NMs, since larger-sized or insoluble NMs will sediment over time and thus show limited nanotoxicity in inverted cell cultures [79,80,82].

The cell culture using an air-liquid interface is commonly used to assess toxicity for respiratory cells in vitro, and it is also regarded as a more cost-effective method compared to their in vivo counterparts $[83,84]$. 
In this method, the media is supplied to the cells from below. As such, the cell surface is exposed, which enables direct contact with the airborne NM, thereby more closely mimicking the in vivo lung situation [83-85].

\subsubsection{D Models}

A co-culture comprises of two or more cell types (e.g., lung tissue composed of alveolar cells and macrophages). They are not necessarily 3D; however, they do provide more relevant information than a multitude of 2D models, since they offer additional cell-cell contact that promotes in vivo-like cell-cell interactions and cross-talk. These interactions and cellular responses provide a more relevant and in-depth $\mathrm{NM}$ toxicity research model. For example, the inclusion of macrophages into a tissue model not only enables research on the direct NM toxicity, but also the indirect toxicity mechanism where NM internalization by macrophages leads to an inflammatory response and subsequent tissue damage [86].

Spheroid microtissues consist of closely connected cells cultured together, thereby enabling the cells to aggregate into a tight three-dimensional ball. A spheroid introduces a more realistic, yet simplified, 3D architecture with more complex cell-cell interactions and an oxygen and nutrient gradient within the tissue. Moreover, the 3D spheroid in itself offers a barrier to NM distribution and cytotoxicity [86,87]. For example, it was shown that penetration of monodispersed drug-silica nanoconjugates was dependent upon size, with smaller NMs penetrating deeper in vivo [88]. A multicellular spheroid, or an organoid, resembles even more closely the in vivo organ $[89,90]$. These tissues have enhanced morphologies and show increased functional activity (e.g., cell communication or a greater secretion of proteins and molecules), which all play a role in the NM uptake and subsequent cellular response [86]. The InSphero ${ }^{\mathrm{TM}}$ model comprising of primary human liver spheroids has even been used to study the nanotoxicity of a range of industrially relevant NMs (e.g., zinc oxide, silver, and $\mathrm{TiO}_{2}$ ) [89].

The incorporation of tissues or organs on a microfluidic platform (Organ-on-Chip; OoC) enables the evaluation of NM nanotoxicity in highly dynamic conditions in vitro [91]. An OoC provides more control and is able to more accurately mimic the in vivo microenvironment of the tissue. Moreover, it also provides more physiological control over the NM presentation and dosimetry. Since the NMs are dispersed in media, it also includes physical and chemical interactions that can occur between the NM and the media [92]. However, the small sizes of the platform lead to more dominant surface effects inside the channels, which can lead to surface adsorption of the NMs. Moreover, the preferred laminar flow inside the chip prohibits the solutions from mixing, which can be problematic when evaluating nanotoxicity.

Precision-cut tissue slices (PCS) still retain the tissues' native architecture and is thus a relatively novel approach to mimic the in vivo microenvironment [93]. It is compatible with a range of tissue samples from different species such as rodents and humans. PCS is especially popular for determining the nanotoxicity in lung [94] and liver tissue [95]. One study determined the nanotoxicity from a range of industrial relevant $\mathrm{NMs}$ (e.g., $\mathrm{TiO}_{2}, \mathrm{ZnO}, \mathrm{Ag}$, and multi-walled carbon nanotubes) [96]. Despite the wide range of use, slicing of the tissue does result in tissue damage on the surface which can generate inflammatory responses. This can interfere with the results of subsequent studies. Moreover, only a limited number of slices can be generated from one organ [97]. Advantages and drawbacks of various in vitro methods are summarized in Table 1.

\subsection{In Vivo}

\subsubsection{Aquatic Models}

A popular biomethod to screen for NMs toxicity internationally is the toxicity test with freshwater Daphnia magna and Dapnia pulex, which are small planktonic crustaceans. These methods have aided in 
determining the exact mechanism of acute and chronic nanotoxicity. Moreover, due to the strict guidelines and standards of the test, the NM effect on mortality and reproduction is easily monitored. It should be noted that crustaceans are primarily used as a pre-screening method, as the biological differences between humans and these crustaceans are too large to conclude anything final on nanotoxicity [98].

Table 1. The advantages and drawbacks of the various in vitro methods.

\begin{tabular}{|c|c|c|c|}
\hline Type & Advantages & Drawbacks & References \\
\hline \multicolumn{4}{|l|}{ 2D cell culture } \\
\hline Upright NM exposure & $\begin{array}{l}\text { Easy experiment set-up; } \\
\text { Can be used for virtually all 2D cell cultures; }\end{array}$ & $\begin{array}{l}\text { Agglomeration of nanoparticles; } \\
\text { Inconsistent protocols between } \\
\text { studies; Inhomogeneous distribution } \\
\text { over time }\end{array}$ & [78] \\
\hline Surface-based NM presentation & $\begin{array}{l}\text { Exact } \mathrm{NM} / \mu \mathrm{m} ; \\
\text { No agglomeration of particles; } \\
\text { Homogeneous distribution over time } \\
\text { Easy monitoring of uptake and toxicity }\end{array}$ & $\begin{array}{l}\text { NM-substrate interactions influence } \\
\text { internalization and toxicity results; } \\
\text { Only static conditions can be tested. }\end{array}$ & [99] \\
\hline Inverted cell culture & Assessment of buoyant NM nanotoxicity & $\begin{array}{l}\text { Limited use for larger-sized or } \\
\text { insoluble NMs }\end{array}$ & [79-82] \\
\hline Air liquid interface & $\begin{array}{l}\text { More physiologically relevant; } \\
\text { Cheaper than in vivo studies; } \\
\text { Range of commercially devices available }\end{array}$ & $\begin{array}{l}\text { Limited to airborne NMs; } \\
\text { Only relevant to nanotoxicity studies } \\
\text { related to inhalation }\end{array}$ & {$[83,85]$} \\
\hline \multicolumn{4}{|l|}{ 3D cell culture } \\
\hline Co-culture & $\begin{array}{l}\text { Promotes in vivo-like cell-cell interactions; } \\
\text { More relevant than 2D nanotoxicity platforms; }\end{array}$ & Still lacks 3D microenvironment & {$[86]$} \\
\hline Spheroids and organoids & $\begin{array}{l}\text { More in vivo-like complexity; } \\
\text { Oxygen and nutrient gradient; } \\
\text { Barrier to NMs distribution and nanotoxicity; } \\
\text { Easy-to-use protocols }\end{array}$ & $\begin{array}{l}\text { Heterogeneity; } \\
\text { Lower reproducibility; } \\
\text { Simplified 3D architecture; } \\
\text { No high throughput }\end{array}$ & {$[86,87,89,90]$} \\
\hline Organ-on-Chip & $\begin{array}{l}\text { High throughput; } \\
\text { Low cost; } \\
\text { Physiologically relevant microenvironment; } \\
\text { Precise control over NM presentation } \\
\text { and dosimetry }\end{array}$ & $\begin{array}{l}\text { Surface effects stemming from } \\
\text { small dimensions; } \\
\text { Little mixing of solutions; } \\
\text { Difficult integration of sensors; }\end{array}$ & {$[91,92]$} \\
\hline Precision-cut tissue slices & $\begin{array}{l}\text { Compatible with a range of tissue samples and } \\
\text { animal species; } \\
\text { High reproducibility; Quickly obtainable; } \\
\text { Retain the tissue native architecture }\end{array}$ & $\begin{array}{l}\text { Tissue damage due to slicing; } \\
\text { Limited number of slices per organ }\end{array}$ & {$[93-97]$} \\
\hline
\end{tabular}

The most widely used aquatic biological and nanotoxicity model are zebrafish, which have a similar developmental process and genome to mammals and also humans [100]. Since embryogenesis occurs outside of the womb and the embryos are transparent, the developmental period is easily monitored. Moreover, embryogenesis is rapid, with structures as the brain, muscle and skeleton already formed $24 \mathrm{~h}$ post fertilization (hpf), and sensory organs such as eyes and ears formed after 5 days post fertilization. The genome of the zebrafish has also been mapped completely, which allowed the production of standardized microarrays for nanotoxicological studies. This enables researchers to perform rapid and large-scale nanotoxicity experiments. Moreover, the use of zebrafish allows testing of NMs through multiple exposure routes, including direct dispersion in water. However, the rapid developmental process also makes it difficult to perform systemic embryo-based nanotoxicity assays [101-104].

\subsubsection{Small Rodents}

The most frequently used in vivo models to determine nanotoxicity are still mammal models, especially small rodents such as mice, rats, and rabbits. These are mainly used because of their close resemblance to humans, they are easier (and cheaper) to be maintained than larger animals such as pigs, which are genetically very close to humans [105]. Many different toxicity studies have been devised, 
including single and multiple administration to assess acute toxicity and chronic nanotoxicity, respectively. The Organisation for Economic Co-operation and Development (OECD) has even devised guidelines to evaluate the in vivo oral, dermal, and $\mathrm{LD}_{50}$ nanotoxicity. Moreover, small rodents can be used to test many different exposure routes, including NM inhalation, intravenous or intraperitoneal injections, ingestion, intra-tracheal installation, or gavage. The most used techniques for exposure to receptors are intravenous and the inhalation of nanoparticles [106]. The main concern regarding nanotechnology is the access of nanoparticles to the circulatory system. Therefore, some studies have already simulated this situation by injecting suspensions of nanoparticles directly into the bloodstream of rats [107]. In these tests, healthy animals with similar mass receive known doses of a given nanoparticle suspended in a certain non-harmful liquid. Usually after $48 \mathrm{~h}$ of the administration of the particles, blood samples are taken for cell counting (such as monocytes, granulocytes, lymphocytes, platelets, red blood cells). Additionally, the measurements of hemoglobin concentration are conducted. This type of test can also be used to assess the distribution and/or bioaccumulation of nanoparticles in vital organs. Moreover, thanks to this procedure, it is also possible to evaluate the distribution of the nanomaterial in the body, which is important for the pharmaceutical industry in the case of purpose of using the particles as nanotransporters [108]. Most of the studies that have searched for the correlation between the effects of nanoparticles inhalation were carried out in vitro using cells of bronchi and alveoli of lungs [109]. On the other hand, in vivo injections using suspensions of nanoparticles applied into the trachea of rats were also used. Thereupon, the relevant changes in the respiratory system might be observed [110]. The trend in in vivo tests has pointed to the simulation of contaminated atmospheres, as was observed by Bermudez et al., who have exposed mice, rats, and hamsters to a $\mathrm{TiO}_{2}$ aerosol inside a sealed container under normal oxygenation conditions, thereby observing inflammation of the alveoli [111]. Advantages and drawbacks of various in vivo methods are summarized in Table 2.

Table 2. The advantages and drawbacks of the various in vivo methods. ADME: Absorption, distribution, metabolism, and excretion.

\begin{tabular}{|c|c|c|c|}
\hline Type & Advantages & Drawbacks & Source(s) \\
\hline \multicolumn{4}{|l|}{ Aquatic models } \\
\hline Planktonic crustaceans & $\begin{array}{l}\text { Standardized protocols and guidelines; } \\
\text { Easy implementation }\end{array}$ & $\begin{array}{l}\text { Primarily used as pre-screening method; } \\
\text { Large biological difference to humans }\end{array}$ & {$[98]$} \\
\hline Zebrafish & $\begin{array}{l}\text { High throughput; } \\
\text { Similar genome; } \\
\text { Rapid developmental process; } \\
\text { Low cost; } \\
\text { Easy monitoring of embryogenesis; } \\
\text { ADME effects studied }\end{array}$ & $\begin{array}{l}\text { Difficult monitoring of rapid developmental } \\
\text { process; } \\
\text { Ethical concerns; } \\
\text { Species to species variation }\end{array}$ & {$[100,101,104]$} \\
\hline \multicolumn{4}{|l|}{ Mammal models } \\
\hline Small rodents & $\begin{array}{l}\text { Multiple routes of exposure; } \\
\text { Guidelines exist to evaluate nanotoxicity; } \\
\text { ADME effects studied; } \\
\text { Chronic effects studied }\end{array}$ & $\begin{array}{l}\text { Ethical concerns; } \\
\text { Species to species variation; Expertise necessary; } \\
\text { High cost }\end{array}$ & {$[105,106]$} \\
\hline
\end{tabular}

\section{The Impact of Nanoparticles: In Vitro and In Vivo Studies}

Titanium dioxide and silver nanoparticles are the most commonly used nanomaterials due to their versatility and functionality in various areas as health, environment, and industries with a positive impact in the economy.

\subsection{Titanium Dioxide Nanoparticles}

Titanium dioxide $\left(\mathrm{TiO}_{2}\right)$ is used in various materials (e.g., paper, plastic, ceramics, rubber, printer ink, floor coverings, catalysts, fabrics and textiles, cosmetics, food colors, medicines, paints, coatings, 
and electronic components). The different types of $\mathrm{TiO}_{2}$-based $\mathrm{NMs}$ can be distinguished by four different crystalline structures: rutile, anatase, brookite, or titanium dioxide [112], with rutile and anatase the most frequently used in products consumption [113].

The National Institute for Occupational Safety and Health (NIOSH) has recommended the general exposure limits of $0.3 \mathrm{mg} / \mathrm{m}^{3}$ of air for the nano form of $\mathrm{TiO}_{2}$ [114]. According to the review presented by $\mathrm{NIOSH}$, five epidemiological studies have already been carried out on the $\mathrm{TiO}_{2} \mathrm{NPs}$ exposure of workers, which showed no relation between $\mathrm{TiO}_{2} \mathrm{NPs}$ and the mortality or morbidity from lung cancer. Thus, $\mathrm{NIOSH}$ have considered that there is insufficient evidence to classify $\mathrm{TiO}_{2} \mathrm{NPs}$ as potential carcinogens in an occupational context. However, according to the classification of the International Agency for Research on Cancer (IARC), $\mathrm{TiO}_{2} \mathrm{NPs}$ are considered as "possibly carcinogenic to humans"; since $\mathrm{TiO}_{2} \mathrm{NPs}$ have shown carcinogenic effects and genotoxicity in animals, its genotoxic potential has also confirmed [114,115]. Moreover, present in vitro tests using bacteria have not proved genotoxicity induced by titanium dioxide, while the positive effects have been reported in eukaryotic cells and in animals [116].

In addition, $\mathrm{TiO}_{2}$ has attracted more and more attention as an effective nanomaterial for the photocatalytic reduction of carbon dioxide $\left(\mathrm{CO}_{2}\right)$ [117]. It has been combined with intermittent and renewable solar energy storage in the form of connections chemicals in order to convert anthropogenic $\mathrm{CO}_{2}$ gas into fuels. Recently, there has been considerable progress in the improvement of the performance of $\mathrm{TiO}_{2}$ photocatalysts in reducing $\mathrm{CO}_{2}$ [117].

In 1997, the accumulation of $\mathrm{TiO}_{2} \mathrm{NPs}$ and the alteration of gene expression were studied by a zebrafish model (Danio rerio). The results revealed that long-term exposure to low concentrations of $\mathrm{TiO}_{2} \mathrm{NPs}_{\text {is }}$ toxic to the reproductive system of this species [73]. Moreover, they concluded that long-term exposure of these nanoparticles is similar to that caused by many toxic reproductive substances, such as endocrine chemicals. In 2010, scientists demonstrated the transfer of $\mathrm{TiO}_{2} \mathrm{NPs}$ from the water flea (Daphnia) to the zebrafish through the freshwater food chain [118]. These researchers have also found that prolonged exposure to low doses of $\mathrm{TiO}_{2} \mathrm{NPs}$ can alter the reproduction of certain aquatic organisms. Ultimately, they showed that these reproductive changes can cause disturbances in the population dynamics of these organisms in aquatic environments. It was also observed that prolonged exposure to $\mathrm{TiO}_{2} \mathrm{NPs}$ negatively affected the reproduction of zebrafish [119], as well as the survival of embryos, regardless of their concentration [102,120]. Moreover, histological analysis and a study on the gene expression showed a delay in folliculogenesis (maturation of the ovarian follicle), as well as changes in the maturation and function of the ovaries of fish exposed to $\mathrm{TiO}_{2} \mathrm{NPs}$. Thus, it has been confirmed once more that these nanoparticles can be toxic at the level of the reproductive system of this species [119].

These results suggest that the contamination of aquatic environments with $\mathrm{TiO}_{2} \mathrm{NPs}$, even at low doses, may have an impact on the reproduction of species [121]. The effect should constitute another reason for investigation the potential impact of $\mathrm{TiO}_{2} \mathrm{NPs}$ on the environment and the human health [119].

\subsection{Silver Nanoparticles}

Silver nanoparticles (AgNPs) are currently one of the most studied nanomaterials [20,64,65,122-124]. These nanoparticles are the most used from an industrial and commercial point of view, due to their characteristic properties (e.g., chemical stability, malleability, flexibility, high electrical and thermal conductivity, catalytic activity, relatively low production cost, and antimicrobial action against bacteria, viruses, fungi, and protozoa). Thus, AgNPs are widely used in various applications and commercial products, such as antibacterial, antifungal, antiviral, anti-inflammatory, anti-tumor, regenerative, biosensor, and catalyst agents [125]. Moreover, they are also present in products in the food, textile, perfumery, pharmaceutical, agricultural, hygiene, cleaning products, paints, electronics industries, among others, leading to human and environmental exposure [126]. Furthermore, AgNPs have wide applicability in 
medicine, e.g., to cover the medical devices, to prepare the nanogels, or to produce the formulations for skin lesions $[64,65,123,127]$.

The control of the parameters during the synthesis of AgNPs is necessary to guarantee the reproducibility of their production. The toxicity of AgNPs depends on several parameters, such as the preparation of the colloidal suspension, the aggregation state, the chemical nature of nanoparticles, the dose, the nature of the living organism, the cell type, the morphology, and the surface size [128,129].

In general, it has been noticed that low concentrations of AgNPs show insignificant toxicity within in vitro and in vivo assays. However, with the increase of the AgNPs concentration, the toxicity of nanoparticles and their accumulation in various tissues/organs tend to increase. In high concentrations, the inhalation or ingestion of AgNPs can cause adverse effects and even lead to tissue death [128].

Currently, toxicological studies of AgNPs in zebrafish are still in the exploration phase. Griffittet et al. (2008) [130] have measured the toxicity of metallic and soluble nanoparticles in zebrafish using static 48-hour bioassays. The obtained results have indicated that the 48-hour $\mathrm{LC}_{50}$ of AgNPs $(26.6 \mathrm{~nm})$ was 7.07 and $7.20 \mathrm{mg} / \mathrm{L}$ for adult and juvenile zebrafish, respectively. The $\mathrm{LC}_{50}$ of $48 \mathrm{~h}$ of AgNPs $(18 \mathrm{~nm})$ in deionized water in embryos after three days of incubation with zebrafish was $0.94 \mathrm{mg} / \mathrm{L}$. Moreover, scientists have investigated the acute toxicity of poly vinyl pyrrolidone (PVP)-coated AgNPs (81 nm) to zebrafish and found that the LC50 value of $48 \mathrm{~h}$ was $84 \mu \mathrm{g} / \mathrm{L}$. The different $\mathrm{LC}_{50}$ values of $48 \mathrm{~h}$ of AgNPs in these studies stem from the different parameters on which the toxicity of AgNPs is dependent. The stability of citrate-capped AgNPs and their toxicity on embryonic development of zebrafish have been assessed, showing that large aggregates of AgNPs were relatively non-toxic compared to nanosized particles. Thus, toxicity to zebrafish is based on the size of the particle.

In the oral toxicity study, AgNPs with the size of $56 \mathrm{~nm}$ were analyzed for 90 days of exposure (doses varying from 0 to $500 \mathrm{mg} / \mathrm{kg}$ ). Significant decreases in the body weight of male rats were noticed, while there were no changes in food or water consumption during the exposure period. The scientists concluded that the liver was a target organ of AgNPs, both in male and female rats. Adverse effects were observed with doses of $125 \mathrm{mg} / \mathrm{kg}$ and above [131]. Pinzaru et al. evaluated the toxicity of poly ethylene glycol (PEG)-coated AgNPs in vitro against human keratinocyte cell culture (HaCat) and in vivo in non-invasive tests on mice (rat species) without SKH-1 [132]. The in vitro results showed that at concentrations between 0.1 and $3.0 \mu \mathrm{mol} / \mathrm{L}$, the number of viable cells was not affected during different periods $(24,48$, and $72 \mathrm{~h})$. In turn, the concentrations of 10 and $50 \mu \mathrm{mol} / \mathrm{L}$ have showed a cytotoxic effect induced by nanoparticles, where in 48 and $72 \mathrm{~h}$, the effect was more significant. In turn, the in vivo tests using mice, where a dose of $10 \mathrm{mg} / \mathrm{kg}$ of AgNPs was administered daily for 6 days, showed that the intraperitoneal injection route did not induce harmful symptoms.

\section{The Importance of Nanosafety}

Nanosafety refers to the assessment of risks to the human health and the environment, as well as to the ecological risks arising from the use of designed nanomaterials and the evaluation of their toxicity level $[133,134]$. The issues facing nano-security stem from the fact that there is often a barrier between the two scientific communities, namely in the field of ecology and ecotoxicology. It is possibly related with customs and methodologies; however, in the assessment of the human toxicity, it is important to communicate between researchers in order to reduce the duplication of efforts and to optimize resources, processes, or research methods [134].

In the last 20 years, studies regarding the nano-security have considerably increased. Some of the studies are contradictory, and they also do not clarify the safety of nanomaterials [135]. Even though it was possible to determine that several nanomaterials were able to penetrate the lungs and gastrointestinal tract, only a small part actually reached the bloodstream and was distributed throughout the body to secondary 
target organs. The vast majority of nanomaterials are captured by macrophages in the lungs or excreted through the feces [51].

According to nanotoxicologists, certain criteria have demonstrated suitable outcomes regarding the characterization and assessment of toxicological risk for carbon nanotubes and fullerenes [136-138]. These criteria stemmed from the most common mistakes committed by the researchers: (1) insufficient characterization often traced back to the supplier, e.g., if the particle size declared by the supplier is incorrect, it will lead to significant errors in subsequent experiments; (2) inadequate testing for contamination of the analyzed nanomaterial. It is important to note that in most of cases, the samples were not treated in sterile conditions; e.g., during the tests that analyze the inflammatory processes, the samples could be contaminated with endotoxins, which initiated the same reaction as inflammatory mediators. Consequently, false positive results are obtained; (3) the interactions of solvents and dispersing agents with the test system are not taken into account; and finally, (4) the lack of control tests, which leads to incomplete conclusions.

The vast majority of the publications have keywords associated with "the toxicological effect", even when the study did not actually prove it due to experimental errors [139]. The lack of conclusive and confirmed data reduces the quality of determining the safety of nanomaterials For example, conducting animal tests to determine the appropriate dosage and to characterize the toxicological risk of NMs for the environment and for the human health is insufficient [140]. Moreover, it has been inferred that laboratories should undergo a standardization process and quality control to reduce any duplication of work. Unfortunately, this phenomenon has become difficult to avoid. With the standardization of epidemiological studies, laboratories should select a sample for using a universal model to allow a comparison of the parameters under evaluation. The analysis of the obtained results must be in accordance with the principles of Good Laboratory Practices and should be carried out by qualified scientists. It seems that these procedures are not taken seriously, since in most cases, the Standard Operating Procedure is not followed, thereby significantly endangering the safety of NMs.

Nanotoxicologists have assessed that not all nanomaterials are created the same way, which means that even when the differences in the properties of the materials are insignificant, differences in the biological response can still occur [133]. The rapid growth in the number of nanomaterials have raised concerns about possible toxic effects on human health and the environment [141]. The greatest concerns stem from the application that requires direct contact with biological systems and those that are part of the constituents of medical devices, as well as pharmaceutical and cosmetic products.

Despite of all the knowledge on nanotoxicity accumulated in the last decade, it is still difficult to predict the bioavailability, biodistribution, degradation, elimination, and biological activity of nanostructures beforehand [142]. However, safety procedures in the manufacture, commercial, and medical industry have been established. Hence, new NMs would benefit from a comprehensive understanding of their toxicological mechanisms and their interaction with the biological system. These studies can illuminate the relation between nanoparticles and its impact on cells (e.g., nanoparticle-cell interactions, endocytosis, and intracellular traffic) $[143,144]$. There are some biological models that are available to check the toxicity of substances or agents in vitro and in vivo. In vitro models are mainly based on isolated cells and can be used in test tubes exposed to the tested substance. In turn, in vivo models are applied to the life organisms in order to observe changes in their development (growth, reproduction, mortality, etc.), which are toxicity indicators. The integration of metabolomics and transcriptomics in nanotoxicity studies is emerging [145].

The tests for NMs need to be reassessed with the perspective of building an appropriate method for the determination of nanotoxicity. In this way, the approaches of biological systems are considered and progressively applied in nano-ecotoxicological sciences. 


\section{Conclusions}

Nanotechnology-based research is intimately related to nanotoxicology and nanosafety. Both of these latter disciplines are complementary and are mainly concerned with the study of the toxicity of nanomaterials and aim to improve the quality of the human life. A constant development in areas such as medicine can bring many benefits for human life and health. However, nanomaterials are being used by several industries and are thus present in many products. Nanomaterials may cause an array of potential toxicological and hazardous effects. Moreover, they can have detrimental effects on many ecosystems. The toxicological risks of using nanomaterials need to be screened, to map the potential risk of causing undesirable effects on the human health and on the environment. Based on recent scientific reports, it has been observed that commonly used methods have helped to design more effective nanomaterials while keeping the hazards of the substances at a minimum. In nanomedicine, the significance of nanotoxicology is particularly important to avoid the toxicity of drug nanocarriers.

Author Contributions: A.Z., B.C., M.V.F., D.M., J.M.S.L., A.D. and M.L. have conceptualized, wrote, and formatted the review. A.Z., B.C., M.V.F., D.M., J.M.S.L., M.M., N.W. and P.E. contributed to the writing of the first draft and preparation of tables and figures. P.E., M.V.C., M.M., N.W., P.S. and E.B.S. contextualized, structured, and reviewed the work. P.S., A.S. and E.B.S. have supervised and managed the funding resources. All authors have read and agreed to the published version of the manuscript.

Funding: This work was supported by the Banco do Nordeste (grant FUNDECI/2016.0015), Conselho Nacional de Desenvolvimento Científico e Tecnológico (CNPq), Fundação de Apoio à Pesquisa e à Inovação Tecnológica do Estado de Sergipe (Fapitec) and Coordenação de Aperfeiçoamento de Pessoal de Nível Superior (CAPES). Eliana B. Souto would like to acknowledge the Portuguese Science and Technology Foundation (FCT/MCT) and from European Funds (PRODER/COMPETE) for the projects M-ERA-NET/0004/2015-PAIRED and UIDB/04469/2020 (strategic fund), co-financed by FEDER, under the Partnership Agreement PT2020.

Conflicts of Interest: The authors declare no conflict of interest.

\section{References}

1. Boverhof, D.R.; Bramante, C.M.; Butala, J.H.; Clancy, S.F.; Lafranconi, M.; West, J.; Gordon, S.C. Comparative assessment of nanomaterial definitions and safety evaluation considerations. Regul. Toxicol. Pharmacol. 2015, 73, 137-150. [CrossRef] [PubMed]

2. Severino, P.; Fangueiro, J.F.; Chaud, M.V.; Cordeiro, J.; Silva, A.M.; Souto, E.B. Advances in nanobiomaterials for topical administrations: New galenic and cosmetic formulations. In Nanobiomaterials in Galenic Formulations and Cosmetics; Elsevier: Amsterdam, The Netherlands, 2016; pp. 1-23.

3. Committee, E.S. Guidance on the risk assessment of the application of nanoscience and nanotechnologies in the food and feed chain. EFSA J. 2011, 9, 2140. [CrossRef]

4. Li, X.; Liu, W.; Sun, L.; Aifantis, K.E.; Yu, B.; Fan, Y.; Feng, Q.; Cui, F.; Watari, F. Effects of physicochemical properties of nanomaterials on their toxicity. J. Biomed. Mater. Res. Part A 2015, 103, 2499-2507. [CrossRef] [PubMed]

5. Shin, S.W.; Song, I.H.; Um, S.H. Role of physicochemical properties in nanoparticle toxicity. Nanomaterials 2015, 5, 1351-1365. [CrossRef]

6. Hobson, D.W.; Roberts, S.M.; Shvedova, A.A.; Warheit, D.B.; Hinkley, G.K.; Guy, R.C. Applied Nanotoxicology. Int. J. Toxicol. 2016, 35, 5-16. [CrossRef] [PubMed]

7. Maynard, A.D. Don't define nanomaterials. Nature 2011, 475, 31. [CrossRef]

8. Salieri, B.; Turner, D.A.; Nowack, B.; Hischier, R. Life cycle assessment of manufactured nanomaterials: Where are we? NanoImpact 2018, 10, 108-120. [CrossRef]

9. Wang, S.; Lu, W.; Tovmachenko, O.; Rai, U.S.; Yu, H.; Ray, P.C. Challenge in understanding size and shape dependent toxicity of gold nanomaterials in human skin keratinocytes. Chem. Phys. Lett. 2008, 463, 145-149. [CrossRef] 
10. Nel, A.; Xia, T.; Mädler, L.; Li, N. Toxic potential of materials at the nanolevel. Science 2006, 311, 622-627. [CrossRef]

11. Schwirn, K.; Voelker, D.; Galert, W.; Quik, J.; Tietjen, L. Environmental Risk Assessment of Nanomaterials in the light of new obligations under the REACH regulation-Which challenges remain and how to approach them? Integr. Environ. Assess. Manag. 2020, 3. [CrossRef]

12. Boros, B.-V.; Ostafe, V. Evaluation of Ecotoxicology Assessment Methods of Nanomaterials and Their Effects. Nanomaterials 2020, 10, 610. [CrossRef] [PubMed]

13. Liu, X.; Tang, K.; Harper, S.; Harper, B.; Steevens, J.A.; Xu, R. Predictive modeling of nanomaterial exposure effects in biological systems. Int. J. Nanomed. 2013, 8, 31. [CrossRef] [PubMed]

14. Hofmann-Amtenbrink, M.; Grainger, D.W.; Hofmann, H. Nanoparticles in medicine: Current challenges facing inorganic nanoparticle toxicity assessments and standardizations. Nanomed. Nanotechnol. Biol. Med. 2015, 11, 1689-1694. [CrossRef] [PubMed]

15. Fu, L.; Wang, Z.; Dhankher, O.P.; Xing, B. Nanotechnology as a new sustainable approach for controlling crop diseases and increasing agricultural production. J. Exp. Bot. 2020, 71, 507-519. [CrossRef] [PubMed]

16. Bandyopadhyay, S.; Peralta-Videa, J.R.; Gardea-Torresdey, J.L. Advanced analytical techniques for the measurement of nanomaterials in food and agricultural samples: A review. Environ. Eng. Sci. 2013, 30, 118-125. [CrossRef]

17. Boateng, E.; Chen, A. Recent advances in nanomaterial-based solid-state hydrogen storage. Mater. Today Adv. 2020, 6, 100022. [CrossRef]

18. Khan, N.I.; Song, E. Lab-on-a-Chip Systems for Aptamer-Based Biosensing. Micromachines 2020, 11, 220. [CrossRef]

19. Singh, P.; Yadava, R. Nanosensors for health care. In Nanosensors for Smart Cities; Elsevier: Amsterdam, The Netherlands, 2020; pp. 433-450.

20. Sánchez-López, E.; Gomes, D.; Esteruelas, G.; Bonilla, L.; Lopez-Machado, A.L.; Galindo, R.; Cano, A.; Espina, M.; Ettcheto, M.; Camins, A.; et al. Metal-Based Nanoparticles as Antimicrobial Agents: An Overview. Nanomaterials 2020, 10, 292. [CrossRef]

21. Attaallah, R.; Antonacci, A.; Arduini, F.; Amine, A.; Scognamiglio, V. Nanobiosensors for Bioclinical Applications: Pros and Cons. In Green Nanoparticles; Springer: Berlin/Heidelberg, Germany, 2020; pp. 117-149.

22. Patil, S.B.; Annese, V.F.; Cumming, D.R. Commercial Aspects of Biosensors for Diagnostics and Environmental Monitoring. In Advances in Nanosensors for Biological and Environmental Analysis; Elsevier: Amsterdam, The Netherlands, 2019; pp. 133-142.

23. Raki, L.; Beaudoin, J.; Alizadeh, R.; Makar, J.; Sato, T. Cement and concrete nanoscience and nanotechnology. Materials 2010, 3, 918-942. [CrossRef]

24. Chakraborty, S.; Jo, B.W.; Yoon, Y.-S. Development of nano cement concrete by top-down and bottom-up nanotechnology concept. In Smart Nanoconcretes and Cement-Based Materials; Elsevier: Amsterdam, The Netherlands, 2020; pp. 183-213.

25. Yang, H.Y.; Han, Z.J.; Yu, S.F.; Pey, K.L.; Ostrikov, K.; Karnik, R. Carbon nanotube membranes with ultrahigh specific adsorption capacity for water desalination and purification. Nat. Commun. 2013, 4, 1-8. [CrossRef]

26. Diallo, M.; Brinker, C.J. Nanotechnology for sustainability: Environment, water, food, minerals, and climate. In Nanotechnology Research Directions for Societal Needs in 2020; Springer: Berlin/Heidelberg, Germany, 2011; pp. 221-259.

27. Yeung, A.W.K.; Souto, E.B.; Durazzo, A.; Lucarini, M.; Novellino, E.; Tewari, D.; Wang, D.; Atanasov, A.G.; Santini, A. Big impact of nanoparticles: Analysis of the most cited nanopharmaceuticals and nanonutraceuticals research. Curr. Res. Biotechnol. 2020, 2, 53-63. [CrossRef]

28. Durazzo, A.; Nazhand, A.; Lucarini, M.; Atanasov, A.G.; Souto, E.B.; Novellino, E.; Capasso, R.; Santini, A. An Updated Overview on Nanonutraceuticals: Focus on Nanoprebiotics and Nanoprobiotics. Int. J. Mol. Sci. 2020, 21, 2285. [CrossRef] [PubMed] 
29. Lucarini, M.; Durazzo, A.; Kiefer, J.; Santini, A.; Lombardi-Boccia, G.; Souto, E.B.; Romani, A.; Lampe, A.; Ferrari Nicoli, S.; Gabrielli, P.; et al. Grape Seeds: Chromatographic Profile of Fatty Acids and Phenolic Compounds and Qualitative Analysis by FTIR-ATR Spectroscopy. Foods 2019, 9, 10. [CrossRef] [PubMed]

30. Campos, J.R.; Severino, P.; Ferreira, C.S.; Zielinska, A.; Santini, A.; Souto, S.B.; Souto, E.B. Linseed Essential Oil - Source of Lipids as Active Ingredients for Pharmaceuticals and Nutraceuticals. Curr. Med. Chem. 2019, 26, 4537-4558. [CrossRef] [PubMed]

31. Souto, E.B.; Zielinska, A.; Souto, S.B.; Durazzo, A.; Lucarini, M.; Santini, A.; Silva, A.M.; Atanasov, A.G.; Marques, C.; Andrade, L.N.; et al. (+)-Limonene 1,2-epoxide-loaded SLN: Evaluation of drug release, antioxidant activity and cytotoxicity in HaCaT cell line. Int. J. Mol. Sci. 2020, 21, E1449. [CrossRef]

32. Singh, A.V.; Laux, P.; Luch, A.; Sudrik, C.; Wiehr, S.; Wild, A.-M.; Santomauro, G.; Bill, J.; Sitti, M. Review of emerging concepts in nanotoxicology: Opportunities and challenges for safer nanomaterial design. Toxicol. Mech. Methods 2019, 29, 378-387. [CrossRef]

33. Xu, Z.; Hou, Y.; Sun, S. Magnetic core/shell $\mathrm{Fe}_{3} \mathrm{O}_{4} / \mathrm{Au}$ and $\mathrm{Fe}_{3} \mathrm{O}_{4} / \mathrm{Au} / \mathrm{Ag}$ nanoparticles with tunable plasmonic properties. J. Am. Chem. Soc. 2007, 129, 8698-8699. [CrossRef]

34. Kong, B.; Seog, J.H.; Graham, L.M.; Lee, S.B. Experimental considerations on the cytotoxicity of nanoparticles. Nanomedicine 2011, 6, 929-941. [CrossRef]

35. Yemmireddy, V.K.; Hung, Y.C. Using photocatalyst metal oxides as antimicrobial surface coatings to ensure food safety-Opportunities and challenges. Compr. Rev. Food Sci. Food Saf. 2017, 16, 617-631. [CrossRef]

36. Zhang, H.; Ji, Z.; Xia, T.; Meng, H.; Low-Kam, C.; Liu, R.; Pokhrel, S.; Lin, S.; Wang, X.; Liao, Y.-P. Use of metal oxide nanoparticle band gap to develop a predictive paradigm for oxidative stress and acute pulmonary inflammation. ACS Nano 2012, 6, 4349-4368. [CrossRef]

37. Guerrini, L.; Alvarez-Puebla, R.A.; Pazos-Perez, N. Surface modifications of nanoparticles for stability in biological fluids. Materials 2018, 11, 1154. [CrossRef] [PubMed]

38. Braakhuis, H.M.; Park, M.V.; Gosens, I.; De Jong, W.H.; Cassee, F.R. Physicochemical characteristics of nanomaterials that affect pulmonary inflammation. Part. Fibre Toxicol. 2014, 11, 18. [CrossRef] [PubMed]

39. Sukhanova, A.; Bozrova, S.; Sokolov, P.; Berestovoy, M.; Karaulov, A.; Nabiev, I. Dependence of nanoparticle toxicity on their physical and chemical properties. Nanoscale Res. Lett. 2018, 13, 44. [CrossRef]

40. Souto, E.B.; Campos, J.R.; Da Ana, R.; Martins-Gomes, C.; Silva, A.M.; Souto, S.B.; Lucarini, M.; Durazzo, A.; Santini, A. Ocular Cell Lines and Genotoxicity Assessment. Int. J. Environ. Res. Public Health 2020, $17,2046$. [CrossRef] [PubMed]

41. Doktorovova, S.; Souto, E.B.; Silva, A.M. Nanotoxicology applied to solid lipid nanoparticles and nanostructured lipid carriers - a systematic review of in vitro data. Eur. J. Pharm. Biopharm. 2014, 87, 1-18. [CrossRef] [PubMed]

42. Lee, S.H.; Jun, B.-H. Silver Nanoparticles: Synthesis and application for nanomedicine. Int. J. Mol. Sci. 2019, 20, 865. [CrossRef]

43. Bajaj, S.; Haverty, M.G.; Arróyave, R.; Shankar, S. Phase stability in nanoscale material systems: Extension from bulk phase diagrams. Nanoscale 2015, 7, 9868-9877. [CrossRef]

44. Mourdikoudis, S.; Pallares, R.M.; Thanh, N.T. Characterization techniques for nanoparticles: Comparison and complementarity upon studying nanoparticle properties. Nanoscale 2018, 10, 12871-12934. [CrossRef]

45. Lin, M.; Fu, Z.Y.; Tan, H.R.; Tan, J.P.Y.; Ng, S.C.; Teo, E. Hydrothermal synthesis of $\mathrm{CeO}_{2}$ nanocrystals: Ostwald ripening or oriented attachment? Cryst. Growth Des. 2012, 12, 3296-3303. [CrossRef]

46. Doktorovova, S.; Kovacevic, A.B.; Garcia, M.L.; Souto, E.B. Preclinical safety of solid lipid nanoparticles and nanostructured lipid carriers: Current evidence from in vitro and in vivo evaluation. Eur. J. Pharm. Biopharm 2016, 108, 235-252. [CrossRef]

47. Doktorovova, S.; Silva, A.M.; Gaivao, I.; Souto, E.B.; Teixeira, J.P.; Martins-Lopes, P. Comet assay reveals no genotoxicity risk of cationic solid lipid nanoparticles. J. Appl. Toxicol. 2014, 34, 395-403. [CrossRef] [PubMed]

48. Albanese, A.; Tang, P.S.; Chan, W.C. The effect of nanoparticle size, shape, and surface chemistry on biological systems. Annu. Rev. Biomed. Eng. 2012, 14,1-16. [CrossRef] [PubMed] 
49. Johnston, H.; Pojana, G.; Zuin, S.; Jacobsen, N.R.; Møller, P.; Loft, S.; Semmler-Behnke, M.; McGuiness, C.; Balharry, D.; Marcomini, A. Engineered nanomaterial risk. Lessons learnt from completed nanotoxicology studies: Potential solutions to current and future challenges. Crit. Rev. Toxicol. 2013, 43, 1-20. [CrossRef]

50. Warheit, D.B. Hazard and risk assessment strategies for nanoparticle exposures: How far have we come in the past 10 years? F1000Research 2018, 7. [CrossRef] [PubMed]

51. Borm, P.J.; Robbins, D.; Haubold, S.; Kuhlbusch, T.; Fissan, H.; Donaldson, K.; Schins, R.; Stone, V.; Kreyling, W.; Lademann, J. The potential risks of nanomaterials: A review carried out for ECETOC. Part. Fibre Toxicol. 2006, 3 , 11. [CrossRef]

52. Hjorth, R.; van Hove, L.; Wickson, F. What can nanosafety learn from drug development? The feasibility of "safety by design". Nanotoxicology 2017, 11, 305-312. [CrossRef]

53. Kraegeloh, A.; Suarez-Merino, B.; Sluijters, T.; Micheletti, C. Implementation of safe-by-design for nanomaterial development and safe innovation: Why we need a comprehensive approach. Nanomaterials 2018, 8, 239. [CrossRef]

54. Gottardo, S.; Alessandrelli, M.; Amenta, V.; Atluri, R.; Barberio, G.; Bekker, C.; Bergonzo, P.; Bleeker, E.; Booth, A.; Borges, T. NANoREG Framework for the Safety Assessment of Nanomaterials; European Commission Joint Research Centre: Ispra, Italy, 2017.

55. Mohs, R.C.; Greig, N.H. Drug discovery and development: Role of basic biological research. Alzheimer's Dement. Transl. Res. Clin. Interv. 2017, 3, 651-657.

56. Ahuja, V.; Sharma, S. Drug safety testing paradigm, current progress and future challenges: An overview. J. Appl. Toxicol. 2014, 34, 576-594. [CrossRef]

57. Merlot, C. Computational toxicology-A tool for early safety evaluation. Drug Discov. Today 2010, 15, 16-22. [CrossRef]

58. Siramshetty, V.B.; Nickel, J.; Omieczynski, C.; Gohlke, B.-O.; Drwal, M.N.; Preissner, R. WITHDRAWN-A resource for withdrawn and discontinued drugs. Nucleic Acids Res. 2016, 44, D1080-D1086. [CrossRef] [PubMed]

59. Jeevanandam, J.; Barhoum, A.; Chan, Y.S.; Dufresne, A.; Danquah, M.K. Review on nanoparticles and nanostructured materials: History, sources, toxicity and regulations. Beilstein J. Nanotechnol. 2018, 9, 1050-1074. [CrossRef] [PubMed]

60. Shvedova, A.; Pietroiusti, A.; Kagan, V. Nanotoxicology ten years later: Lights and shadows. Toxicol. Appl. Pharmacol. 2016, 299, 1-2. [CrossRef] [PubMed]

61. Oberdörster, G. Safety assessment for nanotechnology and nanomedicine: Concepts of nanotoxicology. J. Intern. Med. 2010, 267, 89-105. [CrossRef] [PubMed]

62. Gaur, N.; Sharma, N.; Dahiya, A.; Yadav, P.; Ojha, H.; Goyal, R.K.; Sharma, R.K. Toxicity and Regulatory Concerns for Nanoformulations in Medicine. ELSI Handb. Nanotechnol. 2020, 5, 333-357. [CrossRef]

63. de Souza, A.L.; Andreani, T.; de Oliveira, R.N.; Kiill, C.P.; dos Santos, F.K.; Allegretti, S.M.; Chaud, M.V.; Souto, E.B.; Silva, A.M.; Gremiao, M.P. In vitro evaluation of permeation, toxicity and effect of praziquantel-loaded solid lipid nanoparticles against Schistosoma mansoni as a strategy to improve efficacy of the schistosomiasis treatment. Int. J. Pharm. 2014, 463, 31-37. [CrossRef]

64. Diniz, F.R.; Maia, R.C.A.P.; Rannier, L.; Andrade, L.N.; Chaud, M.V.; da Silva, C.F.; Corrêa, C.B.; de Albuquerque Junior, R.L.C.; da Costa, L.P.; Souto, E.B.; et al. Silver nanoparticles-composing alginate/gelatin hydrogel improves wound healing in vivo. Nanomaterials 2020, 10, 390. [CrossRef]

65. Hissae Yassue-Cordeiro, P.; Zandonai, C.H.; Pereira Genesi, B.; Santos Lopes, P.; Sanchez-Lopez, E.; Garcia, M.L.; Camargo Fernandes-Machado, N.R.; Severino, P.; Souto, E.B.; Ferreira da Silva, C. Development of Chitosan/Silver Sulfadiazine/Zeolite Composite Films for Wound Dressing. Pharmaceutics 2019, 11, 535. [CrossRef]

66. Severino, P.; Silveira, E.F.; Loureiro, K.; Chaud, M.V.; Antonini, D.; Lancellotti, M.; Sarmento, V.H.; da Silva, C.F.; Santana, M.H.A.; Souto, E.B. Antimicrobial activity of polymyxin-loaded solid lipid nanoparticles (PLX-SLN): Characterization of physicochemical properties and in vitro efficacy. Eur. J. Pharm. Sci. 2017, 106, 177-184. [CrossRef] 
67. Doktorovova, S.; Santos, D.L.; Costa, I.; Andreani, T.; Souto, E.B.; Silva, A.M. Cationic solid lipid nanoparticles interfere with the activity of antioxidant enzymes in hepatocellular carcinoma cells. Int. J. Pharm. 2014, 471, 18-27. [CrossRef]

68. Souto, E.B.; da Ana, R.; Souto, S.B.; Zielińska, A.; Marques, C.; Andrade, L.N.; Horbańczuk, O.K.; Atanasov, A.G.; Lucarini, M.; Durazzo, A.; et al. In Vitro Characterization, Modelling, and Antioxidant Properties of Polyphenon-60 from Green Tea in Eudragit S100-2 Chitosan Microspheres. Nutrients 2020, 12. [CrossRef] [PubMed]

69. Giner-Casares, J.J.; Henriksen-Lacey, M.; Coronado-Puchau, M.; Liz-Marzán, L.M. Inorganic nanoparticles for biomedicine: Where materials scientists meet medical research. Mater. Today 2016, 19, 19-28. [CrossRef]

70. Marambio-Jones, C.; Hoek, E.M. A review of the antibacterial effects of silver nanomaterials and potential implications for human health and the environment. J. Nanoparticle Res. 2010, 12, 1531-1551. [CrossRef]

71. Lee, J.; Mahendra, S.; Alvarez, P.J. Nanomaterials in the construction industry: A review of their applications and environmental health and safety considerations. ACS Nano 2010, 4, 3580-3590. [CrossRef]

72. Nel, A.E.; Mädler, L.; Velegol, D.; Xia, T.; Hoek, E.M.; Somasundaran, P.; Klaessig, F.; Castranova, V.; Thompson, M. Understanding biophysicochemical interactions at the nano-bio interface. Nat. Mater. 2009, 8, 543-557. [CrossRef]

73. Bian, W.-P.; Pei, D.-S. Zebrafish model for safety and toxicity testing of nutraceuticals. In Nutraceuticals; Elsevier: Amsterdam, The Netherlands, 2016; pp. 333-339.

74. Hadrup, N.; Loeschner, K.; Mandrup, K.; Ravn-Haren, G.; Frandsen, H.L.; Larsen, E.H.; Lam, H.R.; Mortensen, A. Subacute oral toxicity investigation of selenium nanoparticles and selenite in rats. Drug Chem. Toxicol. 2019, 42, 76-83. [CrossRef]

75. Pamies, D.; Martínez, C.E.; Sogorb, M.A.; Vilanova, E. Mechanism-based models in reproductive and developmental toxicology. In Reproductive and Developmental Toxicology; Elsevier: Amsterdam, The Netherlands, 2011; pp. 135-146.

76. Savage, D.T.; Hilt, J.Z.; Dziubla, T.D. In Vitro Methods for Assessing Nanoparticle Toxicity. In Nanotoxicity; Springer: Berlin/Heidelberg, Germany, 2019; pp. 1-29.

77. van Gestel, C.A.; Loureiro, S. Terrestrial isopods as model organisms in soil ecotoxicology: A review. ZooKeys 2018, 6. [CrossRef]

78. DeLoid, G.M.; Cohen, J.M.; Pyrgiotakis, G.; Demokritou, P. Preparation, characterization, and in vitro dosimetry of dispersed, engineered nanomaterials. Nat. Protoc. 2017, 12, 355-371. [CrossRef]

79. Spyrogianni, A.; Herrmann, I.K.; Lucas, M.S.; Leroux, J.-C.; Sotiriou, G.A. Quantitative analysis of the deposited nanoparticle dose on cell cultures by optical absorption spectroscopy. Nanomedicine 2016, 11, $2483-2496$. [CrossRef]

80. Cho, E.C.; Zhang, Q.; Xia, Y. The effect of sedimentation and diffusion on cellular uptake of gold nanoparticles. Nat. Nanotechnol. 2011, 6, 385-391. [CrossRef]

81. Watson, C.Y.; DeLoid, G.M.; Pal, A.; Demokritou, P. Buoyant Nanoparticles: Implications for Nano-Biointeractions in Cellular Studies. Small 2016, 12, 3172-3180. [CrossRef]

82. Lison, D.; Huaux, F. Ups and downs of cellular uptake. Nat. Nanotechnol. 2011, 6, 332-333. [CrossRef]

83. Clippinger, A.J.; Ahluwalia, A.; Allen, D.; Bonner, J.C.; Casey, W.; Castranova, V.; David, R.M.; Halappanavar, S.; Hotchkiss, J.A.; Jarabek, A.M.; et al. Expert consensus on an in vitro approach to assess pulmonary fibrogenic potential of aerosolized nanomaterials. Arch. Toxicol. 2016, 90, 1769-1783. [CrossRef] [PubMed]

84. Fröhlich, E. Comparison of conventional and advanced in vitro models in the toxicity testing of nanoparticles. Artif. Cells Nanomed. Biotechnol. 2018, 46, 1091-1107. [CrossRef] [PubMed]

85. Geiser, M.; Jeannet, N.; Fierz, M.; Burtscher, H. Evaluating Adverse Effects of Inhaled Nanoparticles by Realistic In Vitro Technology. Nanomaterials 2017, 7, 49. [CrossRef] [PubMed]

86. Singh, N.; Wills, J.W.; Doak, S.H. Three-dimensional Models for In vitro Nanotoxicity Testing. In Nanotoxicology: Experimental and Computational Perspectives; The Royal Society of Chemistry: London, UK, 2018; Chapter 10; pp. 248-275.

87. Joris, F.; Manshian, B.B.; Peynshaert, K.; De Smedt, S.C.; Braeckmans, K.; Soenen, S.J. Assessing nanoparticle toxicity in cell-based assays: Influence of cell culture parameters and optimized models for bridging the in vitro-in vivo gap. Chem. Soc. Rev. 2013, 42, 8339-8359. [CrossRef] 
88. Tang, L.; Gabrielson, N.P.; Uckun, F.M.; Fan, T.M.; Cheng, J. Size-Dependent Tumor Penetration and In Vivo Efficacy of Monodisperse Drug-Silica Nanoconjugates. Mol. Pharm. 2013, 10, 883-892. [CrossRef]

89. Kermanizadeh, A.; Løhr, M.; Roursgaard, M.; Messner, S.; Gunness, P.; Kelm, J.M.; Møller, P.; Stone, V.; Loft, S. Hepatic toxicology following single and multiple exposure of engineered nanomaterials utilising a novel primary human 3D liver microtissue model. Part. Fibre Toxicol. 2014, 11, 56. [CrossRef]

90. Broutier, L.; Andersson-Rolf, A.; Hindley, C.J.; Boj, S.F.; Clevers, H.; Koo, B.-K.; Huch, M. Culture and establishment of self-renewing human and mouse adult liver and pancreas $3 \mathrm{D}$ organoids and their genetic manipulation. Nat. Protoc. 2016, 11, 1724-1743. [CrossRef]

91. Young, E.W.K.; Beebe, D.J. Fundamentals of microfluidic cell culture in controlled microenvironments. Chem. Soc. Rev. 2010, 39, 1036-1048. [CrossRef]

92. Fierz, M.; Houle, C.; Steigmeier, P.; Burtscher, H. Design, Calibration, and Field Performance of a Miniature Diffusion Size Classifier. Aerosol Sci. Technol. 2011, 45, 1-10. [CrossRef]

93. Hartung, T.; Hoffmann, S.; Stephens, M. Mechanistic validation. ALTEX 2013, 30, 119-130. [CrossRef] [PubMed]

94. Lauenstein, L.; Switalla, S.; Prenzler, F.; Seehase, S.; Pfennig, O.; Förster, C.; Fieguth, H.; Braun, A.; Sewald, K. Assessment of immunotoxicity induced by chemicals in human precision-cut lung slices (PCLS). Toxicol. In Vitro 2014, 28, 588-599. [CrossRef] [PubMed]

95. Semmler-Behnke, M.; Kreyling, W.G.; Lipka, J.; Fertsch, S.; Wenk, A.; Takenaka, S.; Schmid, G.; Brandau, W. Biodistribution of 1.4- and 18-nm Gold Particles in Rats. Small 2008, 4, 2108-2111. [CrossRef] [PubMed]

96. Sauer, U.G.; Vogel, S.; Aumann, A.; Hess, A.; Kolle, S.N.; Ma-Hock, L.; Wohlleben, W.; Dammann, M.; Strauss, V.; Treumann, S.; et al. Applicability of rat precision-cut lung slices in evaluating nanomaterial cytotoxicity, apoptosis, oxidative stress, and inflammation. Toxicol. Appl. Pharmacol. 2014, 276, 1-20. [CrossRef] [PubMed]

97. Dragoni, S.; Franco, G.; Regoli, M.; Bracciali, M.; Morandi, V.; Sgaragli, G.; Bertelli, E.; Valoti, M. Gold Nanoparticles Uptake and Cytotoxicity Assessed on Rat Liver Precision-Cut Slices. Toxicol. Sci. 2012, 128, 186-197. [CrossRef]

98. Baun, A.; Hartmann, N.B.; Grieger, K.; Kusk, K.O. Ecotoxicity of engineered nanoparticles to aquatic invertebrates: A brief review and recommendations for future toxicity testing. Ecotoxicology 2008, 17, 387-395. [CrossRef]

99. Villanueva-Flores, F.; Castro-Lugo, A.; Ramírez, O.T.; Palomares, L.A. Understanding cellular interactions with nanomaterials: Towards a rational design of medical nanodevices. Nanotechnology 2020, 31, 132002. [CrossRef]

100. Nishimura, Y.; Inoue, A.; Sasagawa, S.; Koiwa, J.; Kawaguchi, K.; Kawase, R.; Maruyama, T.; Kim, S.; Tanaka, T. Using zebrafish in systems toxicology for developmental toxicity testing. Congenit. Anom. 2016, 56, 18-27. [CrossRef]

101. Chakraborty, C.; Sharma, A.R.; Sharma, G.; Lee, S.-S. Zebrafish: A complete animal model to enumerate the nanoparticle toxicity. J. Nanobiotechnol. 2016, 14, 65. [CrossRef]

102. Haque, E.; Ward, A.C. Zebrafish as a Model to Evaluate Nanoparticle Toxicity. Nanomaterials $2018,8,561$. [CrossRef] [PubMed]

103. Rubinstein, A.L. Zebrafish assays for drug toxicity screening. Expert Opin. Drug Metab. Toxicol. 2006, 2, 231-240. [CrossRef] [PubMed]

104. Spitsbergen, J.M.; Kent, M.L. The state of the art of the zebrafish model for toxicology and toxicologic pathology research-advantages and current limitations. Toxicol. Pathol. 2003, 31, 62-87. [CrossRef]

105. Richmond, J. Refinement, Reduction, and Replacement of Animal Use for Regulatory Testing: Future Improvements and Implementation Within the Regulatory Framework. ILAR J. 2002, 43, S63-S68. [CrossRef] [PubMed]

106. Armstead, A.L.; Li, B. Nanotoxicity: Emerging concerns regarding nanomaterial safety and occupational hard metal (WC-Co) nanoparticle exposure. Int. J. Nanomed. 2016, 11, 6421-6433. [CrossRef]

107. Patra, J.K.; Das, G.; Fraceto, L.F.; Campos, E.V.R.; del Pilar Rodriguez-Torres, M.; Acosta-Torres, L.S.; Diaz-Torres, L.A.; Grillo, R.; Swamy, M.K.; Sharma, S. Nano based drug delivery systems: Recent developments and future prospects. J. Nanobiotechnol. 2018, 16, 71. [CrossRef]

108. Küchler, S.; Radowski, M.R.; Blaschke, T.; Dathe, M.; Plendl, J.; Haag, R.; Schäfer-Korting, M.; Kramer, K.D. Nanoparticles for skin penetration enhancement-A comparison of a dendritic core-multishell-nanotransporter and solid lipid nanoparticles. Eur. J. Pharm. Biopharm. 2009, 71, 243-250. [CrossRef] 
109. Paranjpe, M.; Müller-Goymann, C.C. Nanoparticle-mediated pulmonary drug delivery: A review. Int. J. Mol. Sci. 2014, 15, 5852-5873. [CrossRef]

110. Oberdörster, G.; Kuhlbusch, T.A. In vivo effects: Methodologies and biokinetics of inhaled nanomaterials. NanoImpact 2018, 10, 38-60. [CrossRef]

111. Bermudez, E.; Mangum, J.B.; Wong, B.A.; Asgharian, B.; Hext, P.M.; Warheit, D.B.; Everitt, J.I. Pulmonary responses of mice, rats, and hamsters to subchronic inhalation of ultrafine titanium dioxide particles. Toxicol. Sci. 2004, 77, 347-357. [CrossRef]

112. Kobayashi, K.; Kubota, H.; Hojo, R.; Miyagawa, M. Effective dispersal of titanium dioxide nanoparticles for toxicity testing. J. Toxicol. Sci. 2019, 44, 515-521. [CrossRef]

113. Uboldi, C.; Urbán, P.; Gilliland, D.; Bajak, E.; Valsami-Jones, E.; Ponti, J.; Rossi, F. Role of the crystalline form of titanium dioxide nanoparticles: Rutile, and not anatase, induces toxic effects in Balb/3T3 mouse fibroblasts. Toxicol. In Vitro 2016, 31, 137-145. [CrossRef] [PubMed]

114. Oberbek, P.; Kozikowski, P.; Czarnecka, K.; Sobiech, P.; Jakubiak, S.; Jankowski, T. Inhalation exposure to various nanoparticles in work environment—contextual information and results of measurements. J. Nanoparticle Res. 2019, 21, 222. [CrossRef]

115. Skocaj, M.; Filipic, M.; Petkovic, J.; Novak, S. Titanium dioxide in our everyday life; is it safe? Radiol. Oncol. 2011, 45, 227-247. [CrossRef]

116. Wong, S.W.; Leung, P.T.; Djurišić, A.; Leung, K.M. Toxicities of nano zinc oxide to five marine organisms: Influences of aggregate size and ion solubility. Anal. Bioanal. Chem. 2010, 396, 609-618. [CrossRef] [PubMed]

117. Nguyen, T.P.; Nguyen, D.L.T.; Nguyen, V.-H.; Le, T.-H.; Vo, D.-V.N.; Trinh, Q.T.; Bae, S.-R.; Chae, S.Y.; Kim, S.Y.; Le, Q.V. Recent Advances in $\mathrm{TiO}_{2}$-Based Photocatalysts for Reduction of $\mathrm{CO}_{2}$ to Fuels. Nanomaterials 2020, 10, 337. [CrossRef] [PubMed]

118. Lekamge, S.; Miranda, A.F.; Ball, A.S.; Shukla, R.; Nugegoda, D. The toxicity of coated silver nanoparticles to Daphnia carinata and trophic transfer from alga Raphidocelis subcapitata. PLoS ONE 2019, 14. [CrossRef]

119. Bai, C.; Tang, M. Toxicological study of metal and metal oxide nanoparticles in zebrafish. J. Appl. Toxicol. 2020, 40, 37-63. [CrossRef]

120. Wang, Y.-J.; He, Z.-Z.; Fang, Y.-W.; Xu, Y.; Chen, Y.-N.; Wang, G.-Q.; Yang, Y.-Q.; Yang, Z.; Li, Y.-H. Effect of titanium dioxide nanoparticles on zebrafish embryos and developing retina. Int. J. Ophthalmol. 2014, 7, 917.

121. Ramsden, C.; Henry, T.; Handy, R. Sub-lethal effects of titanium dioxide nanoparticles on the physiology and reproduction of zebrafish. Aquat. Toxicol. 2013, 126, 404-413. [CrossRef]

122. Ottoni, C.; Neto, M.L.; Léo, P.; Ortolan, B.; Barbieri, E.; De Souza, A. Environmental impact of biogenic silver nanoparticles in soil and aquatic organisms. Chemosphere 2020, 239, 124698. [CrossRef] [PubMed]

123. Barbosa, G.P.; Debone, H.S.; Severino, P.; Souto, E.B.; da Silva, C.F. Design and characterization of chitosan/zeolite composite films-Effect of zeolite type and zeolite dose on the film properties. Mater. Sci. Eng. C 2016, 60, 246-254. [CrossRef] [PubMed]

124. Teixeira, M.C.; Carbone, C.; Sousa, M.C.; Espina, M.; Garcia, M.L.; Sanchez-Lopez, E.; Souto, E.B. Nanomedicines for the Delivery of Antimicrobial Peptides (AMPs). Nanomaterials 2020, 10, 560. [CrossRef] [PubMed]

125. Franci, G.; Falanga, A.; Galdiero, S.; Palomba, L.; Rai, M.; Morelli, G.; Galdiero, M. Silver nanoparticles as potential antibacterial agents. Molecules 2015, 20, 8856-8874. [CrossRef]

126. Marin, S.; Mihail Vlasceanu, G.; Elena Tiplea, R.; Raluca Bucur, I.; Lemnaru, M.; Minodora Marin, M.; Mihai Grumezescu, A. Applications and toxicity of silver nanoparticles: A recent review. Curr. Top. Med. Chem. 2015, 15, 1596-1604. [CrossRef]

127. Wei, L.; Lu, J.; Xu, H.; Patel, A.; Chen, Z.-S.; Chen, G. Silver nanoparticles: Synthesis, properties, and therapeutic applications. Drug Discov. Today 2015, 20, 595-601. [CrossRef]

128. Liao, C.; Li, Y.; Tjong, S.C. Bactericidal and cytotoxic properties of silver nanoparticles. Int. J. Mol. Sci. 2019, 20, 449. [CrossRef]

129. Calderón-Jiménez, B.; Johnson, M.E.; Montoro Bustos, A.R.; Murphy, K.E.; Winchester, M.R.; Vega Baudrit, J.R. Silver nanoparticles: Technological advances, societal impacts, and metrological challenges. Front. Chem. 2017, 5, 6. [CrossRef] 
130. Griffitt, R.J.; Luo, J.; Gao, J.; Bonzongo, J.-C.; Barber, D.S. Effects of particle composition and species on toxicity of metallic nanomaterials in aquatic organisms. Environ. Toxicol. Chem. 2008, 27, 1972-1978. [CrossRef]

131. Kim, Y.S.; Song, M.Y.; Park, J.D.; Song, K.S.; Ryu, H.R.; Chung, Y.H.; Chang, H.K.; Lee, J.H.; Oh, K.H.; Kelman, B.J. Subchronic oral toxicity of silver nanoparticles. Part. Fibre Toxicol. 2010, 7, 20. [CrossRef]

132. Pinzaru, I.; Coricovac, D.; Dehelean, C.; Moacă, E.-A.; Mioc, M.; Baderca, F.; Sizemore, I.; Brittle, S.; Marti, D.; Calina, C.D. Stable PEG-coated silver nanoparticles-A comprehensive toxicological profile. Food Chem. Toxicol. 2018, 111, 546-556. [CrossRef] [PubMed]

133. Costa, P.M.; Fadeel, B. Emerging systems biology approaches in nanotoxicology: Towards a mechanism-based understanding of nanomaterial hazard and risk. Toxicol. Appl. Pharmacol. 2016, 299, 101-111. [CrossRef] [PubMed]

134. Kahru, A.; Dubourguier, H.-C. From ecotoxicology to nanoecotoxicology. Toxicology 2010, 269, 105-119. [CrossRef] [PubMed]

135. Krug, H.F. Nanosafety research-are we on the right track? Angew Chem. Int. Ed. Engl. 2014, 53, 12304-12319. [CrossRef] [PubMed]

136. Oberdörster, G.; Castranova, V.; Asgharian, B.; Sayre, P. Inhalation exposure to carbon nanotubes (CNT) and carbon nanofibers (CNF): Methodology and dosimetry. J. Toxicol. Environ. Health Part B 2015, 18, 121-212. [CrossRef] [PubMed]

137. Fatkhutdinova, L.; Khaliullin, T.; Shvedova, A. Carbon nanotubes exposure risk assessment: From toxicology to epidemiologic studies (overview of the current problem). Nanotechnologies Russia 2015, 10, 501-509. [CrossRef]

138. Aschberger, K.; Johnston, H.J.; Stone, V.; Aitken, R.J.; Tran, C.L.; Hankin, S.M.; Peters, S.A.; Christensen, F.M. Review of fullerene toxicity and exposure-Appraisal of a human health risk assessment, based on open literature. Regul. Toxicol. Pharmacol. 2010, 58, 455-473. [CrossRef]

139. Krug, H.F.; Nau, K. Reliability for Nanosafety Research-Considerations on the Basis of a Comprehensive Literature Review. ChemBioEng Rev. 2017, 4, 331-338. [CrossRef]

140. Henschler, D. Toxicological problems relating to changes in the environment. Angew. Chem. Int. Ed. Engl. 1973, 12, 274-283. [CrossRef]

141. Ray, P.C.; Yu, H.; Fu, P.P. Toxicity and environmental risks of nanomaterials: Challenges and future needs. J. Environ. Sci. Health Part C 2009, 27, 1-35. [CrossRef]

142. Zhou, M.; Ge, X.; Ke, D.; Tang, H.; Zhang, J.; Calvaresi, M.; Gao, B.; Sun, L.; Su, Q.; Wang, H. The Bioavailability, Biodistribution and Toxic Effects of Silica-coated Upconversion Nanoparticles in Vivo. Front. Chem. 2019, 7, 218. [CrossRef] [PubMed]

143. Behzadi, S.; Serpooshan, V.; Tao, W.; Hamaly, M.A.; Alkawareek, M.Y.; Dreaden, E.C.; Brown, D.; Alkilany, A.M.; Farokhzad, O.C.; Mahmoudi, M. Cellular uptake of nanoparticles: Journey inside the cell. Chem. Soc. Rev. 2017, 46, 4218-4244. [CrossRef] [PubMed]

144. Panariti, A.; Miserocchi, G.; Rivolta, I. The effect of nanoparticle uptake on cellular behavior: Disrupting or enabling functions? Nanotechnol. Sci. Appl. 2012, 5, 87. [PubMed]

145. Shin, T.H.; Lee, D.Y.; Lee, H.S.; Park, H.J.; Jin, M.S.; Paik, M.J.; Manavalan, B.; Mo, J.S.; Lee, G. Integration of metabolomics and transcriptomics in nanotoxicity studies. BMB Rep. 2018, 51, 14-20. [CrossRef] [PubMed]

(C) 2020 by the authors. Licensee MDPI, Basel, Switzerland. This article is an open access article distributed under the terms and conditions of the Creative Commons Attribution (CC BY) license (http://creativecommons.org/licenses/by/4.0/). 